IFN Working Paper No. 741, 2008

Financial Determinants of Foreign Direct Investment

Jens Forssbæck and Lars Oxelheim 


\section{Financial determinants of foreign direct investment}

Jens Forssbæck, Lund Institute of Economic Research, P.O. Box 7080, 22007 LUND, Sweden, phone + 4646222 4441, fax +46 4622244 37, e-mail: jens.forssbaeck@fek.lu.se;

Center for Law, Economics, and Financial Institutions, Copenhagen Business School, Copenhagen, Denmark

and

Lars Oxelheim, Lund Institute of Economic Research, P.O. Box 7080, 22007 LUND,

Sweden, phone + 4646222 8744, fax +46 4622244 37, e-mail: lars.oxelheim@fek.lu.se;

The Research Institute of Industrial Economics, P.O. Box 55665, 10215 Stockholm, Sweden, phone +46 866545 27, fax +46 8665 4599, e-mail: lars.oxelheim@ifn.se

The authors thank Yair Aharoni, Andrew Delios, Ram Mudambi, Clas Wihlborg, and participants at Financial Management Association and European International Business Academy conferences for useful comments on earlier versions of this paper. 


\title{
Financial determinants of foreign direct investment
}

\begin{abstract}
We argue that mainstream FDI theory underplays financial motivations for international investment, and suggest several possible channels for a distinct cost-of-capital effect on FDI. Using a sample of European firms' cross-border acquisitions, and controlling for traditional firm-level determinants of FDI, we find strong evidence in favor of a cost-of-equity effect, whereas the effect of debt costs is indeterminate. We further find that financial determinants are more important for firms originating in relatively less financially developed countries and for firms with high knowledge intensity.
\end{abstract}

Key words: FDI, cross-border acquisitions, investment-q, cost of capital, crosslisting, segmentation

JEL: E22, F21, F23, G3, L23 
Different theories and research traditions compete about providing the logic behind and the determinants of firms' decisions to undertake foreign direct investment (FDI). However, whether one emphasizes a firm's ownership advantages (e.g. Dunning (1977)), its knowledge capital (Markusen (1984)), or its potential for gaining economies of scale and scope by internalizing transactions (Buckley and Casson (1976); Rugman (1981)), the focus is on real side factors. The financial side, by contrast, is typically allotted the role of a passive source of funds, which smoothly and efficiently responds to firms' needs and demands. Historically, this can be attributed to the fact that mainstream FDI theory has made the (implicit) simplifying assumptions of frictionless financial markets and perfect international financial integration (with some exceptions - see e.g. Aliber (1970)). In addition, FDI theory has generally assumed that direct investments are similar to bonds and other portfolio assets for which the price and the nominal returns are always in the same currency (Blonigen (1997)).

Much of this stands at odds with the current theory of finance and financial markets, and relaxing these assumptions can have potentially far-reaching implications for our understanding of the motivations for cross-border direct investment as well. This can to some extent be illustrated by the progress made in capturing the effect of exchange rates on FDI over the last decade or two (see, e.g., Froot and Stein (1991)) by relaxing the efficient markets assumption. This progress notwithstanding, this paper argues that the role of firm-level financial determinants of FDI remains to be properly considered.

We draw on, inter alia, recent developments in the FDI literature and results on the relationship between finance and domestic investment to argue that a firm's financial position is not merely a by-product of traditional FDI determinants, such as general economies of scale or investment opportunities, but that the assumptions of 
information asymmetries in financial markets and (partial) capital market segmentation between countries open up a number of possible mechanisms which may give rise to a distinct cost of capital effect on cross-border direct investment.

Controlling for 'traditional' FDI determinants, we empirically test the effect of a number of firm-level financial characteristics on the probability of undertaking a cross-border acquisition in a series of binary response (probit) models. The results, based on a sample of 1459 European non-financial firms' cross-border acquisitions in a total of 44 target markets, reveal a consistently significant explanatory power of equity-related finance variables over a number of different specifications, and regardless of the proxy used for equity market valuation. According to expectation, the effect of debt costs, on the other hand, is indeterminate. Financial determinants also prove to be more important for firms originating in countries that are relatively less financially developed (indicating the importance of eliminating a 'financial disadvantage' for an internationalizing firm). Moreover, the hypothesis that financial motivations for FDI are stronger for more knowledge-intensive firms receives strong support from the data, whereas a more general systematic variation in FDI-finance sensitivity by industry cannot be unequivocally inferred.

All in all, the results strengthen the case for a more prominent role for financial explanations of cross-border direct investment, and press for further work exploring the link between finance and FDI.

The article is organized in the following way. Section I outlines a number of mechanisms whereby financial factors can be identified as independent drivers of FDI. The ensuing section presents the empirical methodology. In Section III we present the variables and the dataset. Results are presented and discussed in Section IV, and Section V concludes. 


\section{Financial determinants of FDI}

Existing theories of FDI and of multinationals' cross-border operations have developed along parallel paths within the economics and management literatures, but essentially coincide in terms of the basic explanations of why firms invest across borders. The focus is largely on a firm's ownership of intangible assets that can be exploited by FDI. Because foreign firms are generally at a cost disadvantage relative to local firms when entering a new geographical market, it must have some compensating advantage - often termed an 'ownership advantage' - which is transferable abroad and of such magnitude that it may compensate for the extra costs that are associated with doing business abroad. Such assets, or advantages, may include various economies of scale and scope, ${ }^{1}$ a superior technology, or other types of proprietary knowledge, such as managerial and marketing expertise (Caves (1971)).

Internalization theory (Buckley and Casson (1976); Hymer (1976); Rugman (1981)) views these intangible assets as a firm-specific 'public good' which is transferable within the firm at a lower transaction cost than would be achieved were the asset to be transferred in any other way between different markets. Markusen (1984) and Horstmann and Markusen (1989) argue that this strongly suggests that multinationality (and hence FDI) is more prevalent in industries where knowledge-based assets are important, because the services of such assets are more easily transported internationally, and they can be supplied to additional production sites at virtually zero marginal cost. Within the industrial organization literature, these insights form the basis of what is often called the 'knowledge capital' model of MNCs, whereas in the international business field, ownership advantages and internalization factors often join hands with 'location' factors (such as local market size, wage costs, taxes, etc.) to 
form the so-called 'OLI' framework for explaining why a particular firm undertakes direct investment in a particular destination country (Dunning $(1977,1988))$.

While FDI theory thus largely builds on assumptions of market imperfections, these assumptions have rarely been extended to explicitly include financial markets, or - when they have - focus has been on explaining the effect of exchange rates (rather than firm-level financial characteristics) on FDI (Kogut and Kulatilaka (1994); Froot and Stein (1991); see below). A possible reason is that FDI theory early on made the simplifying assumptions of efficient financial markets and international financial integration, and the theory developed with these assumptions as given. ${ }^{2}$ In addition, some conceivable sources of a 'finance' effect on FDI can clearly be accommodated within existing theory; for example, an 'internal capital markets' view on MNCs (Stein (1997)) marries well with FDI theory if the internal capital market is viewed as an intangible asset which is 'internalized'.

Regardless of the reason, it is clear that financial factors have never quite 'caught on' as an explanation for FDI on equal footing with more general 'asset advantage' and 'internalization' determinants, and we were hard-pressed to find any empirical applications at all considering financial variables from within the FDI literature. De Santis et al. (2004) test stock market valuations (measured by Tobin's $q$ ) as a determinant of Euro area aggregate FDI in the United States 1980-2001, but use Tobin's $q$ as a proxy for traditional FDI determinants - in particular intangible assets. This both homes in on our main message, and puts the finger on an empirical complication: the point of a financial effect on FDI would be that a valuation effect remains after controlling for 'fundamental' (real) factors inherent in that valuation.

Motivating a finance-FDI effect requires the assumption of some degree of international financial market segmentation. This might in itself require some motiva- 
tion, but ample evidence support our view of international capital markets as characterized by what we may term 'partial segmentation'. ${ }^{4}$ Allowing for (partial) segmentation, one can distinguish between two main groups of mechanisms whereby finance could matter for FDI: reactive and proactive firm behavior (Oxelheim et al. (2001)).

The first group refers to firms' responses to financial market imperfections (and international capital market segmentation). The potential role of 'reactive' firm behavior as a determinant of FDI under financial market imperfections was identified early on, and has surfaced in the literature from time to time (but without ever making much of a mark). For instance, Aliber (1970) suggests that capital market segmentation implies that a multinational firm has an advantage over local firms in that its multinationality enables it to raise capital with a lower exchange rate risk premium, and thus a lower overall cost. Assuming more or less permanent capital market segmentation implies that also risk-adjusted capital costs differ across countries, which would in turn - imply a finance-FDI effect in simple discount-factor terms: some countries' firms will find foreign investment projects profitable that are forgone by local firms because in net-present-value terms, local and foreign firms value the project differently.

We do not have to assume permanent segmentation to find valuation effects. The combination of temporary mispricing of company fundamentals by the market and opportunistic managers has been suggested as explanation for 'excessive' stock market effects on investment (both capital expenditure and acquisitions) domestically (see, e.g., Morck et al. (1990); Baker et al. (2003); Shleifer and Vishny (2003); Gilchrist et al. (2005)), and may be extended to the international case under relatively general assumptions. The basic argument is that if the market places a higher value on the firm's fundamentals than the managers, then managers should capitalize on the 
mispricing, issue stock, and invest in positive-NPV projects given the 'mispriced' cost of capital, rather than basing investment policy on their own perception of fundamentals (for a concise exposition of the arguments and counterarguments, see Blanchard et al. (1993)). The international analogy would be to issue stock locally and invest internationally. As noted by Shleifer and Vishny (2003), mispricing may be idiosyncratic or attributable to some specific industry, group of firms, or geographic area. Assuming some degree of correlation between the mispricing of stocks within a country (for example, due to a geographic component in mispricing, or an industry-specific component with distinct industrial structures across countries), cost of capital may drive not only investment and acquisitions domestically, but may represent a particular (temporary) advantage - or disadvantage, in the case of undervaluation - for undertaking foreign investment projects.

Discount-factor-type motivations for a finance-FDI effect are similar to traditional motivations for FDI in that they assume that some firms have an advantage which makes them value foreign investment projects differently than local firms. In fact, a financial influence on FDI may occur even without such valuation effects, in the presence of both financial constraints and capital market segmentation. This type of explanation is analogous with leading theories of the exchange rate effect on FDI. Froot and Stein (1991) is the first widely quoted paper to impose a financial market imperfection as the source of an unequivocal exchange rate effect. They do it by assuming that some, particularly information-intensive, investments cannot be 100 percent externally financed. In this situation, a real depreciation of the 'domestic' currency will enable a 'foreign' bidder to bring more net wealth to the investment at equal cost, thereby outbidding the domestic bidder. The effect occurs despite perfect 
international financial integration and despite equal valuations of the acquired asset/investment by the domestic and the foreign firm (Klein and Rosengren (1994)).

Froot and Stein's (1991) wealth effect presumes a financing constraint akin to the one underpinning 'pecking-order' theories of capital structure: as a consequence of information asymmetries between managers and providers of external capital, the marginal cost of outside debt and equity may exceed the opportunity cost of internal financing, and the firm will therefore prefer to finance a share of investments with cash and retained earnings (Myers and Majluf (1984); Fazzari et al. (1988)) - hence the importance of firm wealth. The authors argue that this type of information asymmetry is much more likely for direct investment projects than for portfolio investments, which are more uniform, and therefore that FDI should be more exchange-rate sensitive than cross-border portfolio investments. They also assume, however, that financing constraints are equal across countries, and that the wealth effect occurs through real exchange rate changes. This follows from the maintained assumption of perfect international capital mobility. Relaxing this assumption, the wealth effect could simply be the effect of differences in financial constraints. There is ample evidence in favor of such differences, not least from the finance-growth literature. ${ }^{5}$

Baker et al. (forthcoming) note that relative wealth shocks of the type that result from exchange rate changes in Froot and Stein (1991) may also originate in stock market price misalignments if such misalignments are not symmetrical across all countries, and if stock market mispricing influences the perception of the firm's collateralizable wealth in the eyes of prospective lenders. They discuss the possibility of an effect on FDI through a 'cheap finance' channel (source-country overvaluation) and/or a 'cheap assets' channel (host-country undervaluation). Testing for these effects on aggregate annual data on in- and outward US FDI over the 1974-2001 period, 
they find strong evidence in favor of a 'cheap finance' effect on FDI. The results, they argue, are evidence of international arbitrage by multinationals, and speculate that this is due to certain advantages of MNCs relative to portfolio investors in conducting arbitrage - the most important being less binding short-sales constraints.

Another advantage of MNCs, which cannot be exploited by portfolio investors, is suggested by Blonigen (1997). The main tenor of Blonigen's contribution is really to suggest an alternative mechanism whereby exchange rates may matter for some acquisition FDI. The 'pull' effect of the target's knowledge-based assets (such as a productivity-enhancing innovation) plays a central role. Blonigen observes that in a segmented production process, such assets are not necessarily similar to portfolio investments where the price and the returns are in the same currency, but may yield returns across a variety of markets and currencies without any exchange rate transactions. These assets may therefore be valued differently by 'foreign' and 'domestic' buyers if the real exchange rate changes, even if the firms have the exact same financing possibilities. ${ }^{6}$ The implication of Blonigen's findings is that exchange rates should be more important as determinants of acquisition FDI within industries where target firms are likely to possess significant (knowledge-based) firm-specific assets.

There are thus several conceivable mechanisms by which firms' reactions to financial market inefficiencies may drive foreign investment. We called this group of explanations 'reactive' firm behavior. The second group refers to proactive motivations for a finance-FDI effect. Here, Oxelheim et al. (2001) also make imperfect financial integration and remaining home bias in world capital markets their point of departure. They assume a two-tier world capital market with partial segmentation between national capital markets, where a local firm can choose to stay in its home market and face the local cost of capital, or invest in 'proactive financial strategies' to in- 
ternationalize its cost of capital and reap the benefits of the economies of scale and scope attributable to a multinational firm. Such financial strategies may include crosslisting its stock in a more liquid stock market (Sundaram and Logue (1996); Foerster and Karolyi (1999); Miller (1999); Pagano et al. (2002)), foreign issues of equity and/or debt (Modén and Oxelheim (1997)), and 'bonding' strategies to reduce information asymmetries (Oxelheim and Randøy (2003)). This type of strategies, they suggest, may foment ownership advantages - or, rather, eliminate a financial disadvantage - and such firms are considerably more likely to continue the internationalization process by undertaking FDI. Tolmunen and Torstila (2005) study one such proactive strategy. They find that European firms that have cross-listed their stock in the US market are significantly more likely to make acquisitions in the US. They interpret the results in terms of the European firms' need for a viable 'M\&A currency', their need to reduce information asymmetries, and overcoming home bias. This is just another way of wording the need to reduce a financial ownership disadvantage. To the extent that a stock listed on, say, the New York Stock Exchange is a more viable acquisition currency not just in the US but anywhere in the world, this effect may hold more generally.

To sum up, if financial markets are to some degree inefficient and/or (partially) segmented internationally, a cost of capital effect on FDI can occur through 'reactive' or 'proactive' firm behavior in response to those inefficiencies. Possible mechanisms for a finance-FDI effect can be derived from theories motivating a finance-investment effect domestically or from theories underpinning an exchange rate effect on FDI. There is much to suggest that finance-specific advantages are more important for firms in more knowledge-intensive industries. We also argued that such advantages are more important for firms resident in countries with relatively illiquid 
and/or segmented domestic capital markets. We cannot distinguish directly between the different mechanisms empirically; instead, we will in what follows indirectly test for various implications of the different mechanisms, present strong evidence that finance does matter, and draw tentative conclusions about which mechanisms are more important. The following section explains the empirical methodology.

\section{Methodology}

Based on the implications of the literature reviewed above, we test three main hypotheses: Hypothesis 1: firms' financial attributes exert a distinct effect (that is, an effect which is independent of fundamentals) on their propensity to undertake foreign direct investment; Hypothesis 2: financial determinants of FDI are more important for firms in industries where investments are more knowledge-intensive and where target firms are more likely to have firm-specific assets that yield returns that are noncurrency-specific; Hypothesis 3: financial determinants of FDI are more pronounced for firms resident in countries with a lower level of financial development. We also subject the results to a number of robustness tests, including tests where we control for location (target-market) effects.

\section{A. Which firms make foreign acquisitions?}

We start by testing Hypothesis 1 in a series of binary response (probit) regression models. The completion of a foreign acquisition is an indicator (dummy) variable, and it is regressed on firm financial characteristics, a set of 'traditional' FDI determinants, and a set of control variables. This gives a general specification of the following form:

$$
A C Q_{i}=\left\{\begin{array}{l}
1 \text { if } A C Q_{i}^{*}>0 \\
0 \text { otherwise }
\end{array}\right.
$$


where

$$
A C Q_{i}^{*}=\alpha+\beta^{\prime} F_{i}+\delta^{\prime} X_{i}+\gamma^{\prime} C_{i}+\varepsilon_{i}
$$

$A C Q_{i}$ denotes the decision by firm $i$ to make a foreign acquisition, $F_{i}$ is a vector of finance-related variables for firm $i, X_{i}$ is a vector of non-financial firm-level determinants of FDI, $C_{i}$ is a set of control variables, and $\varepsilon_{i}$ is an error term. This constitutes our 'baseline regression' model. The simple idea is that if (any of) the included finance-related variables turn out significant, then we would have made a case for our claim that finance matters for FDI. The next set of tests deals with a potentially important empirical complication arising from this basic layout.

\section{B. Financial strength or investment opportunities?}

The empirical complication is that any proxy for the cost of equity we might choose to use in Equation 1 (such as Tobin's $q$-i.e., the market value over the book value of a firm's assets - or other standard ratios for stock market valuation that use the market value or stock price of a firm) may easily be argued to really capture something else than a strictly financial factor. In a standard investment- $q$ equation, $q$ is generally interpreted as a proxy for investment opportunities (domestic or foreign), and so the significance of $q$ (or other candidate valuation measures correlated with it) as a determinant of a firm's propensity to undertake foreign acquisitions in a regression of the type outlined in the previous subsection really reflects an 'ex-finance' factor. Specifically, it is a reflection of the market's rational valuation of the firm's prospects for generating cash flow in the future. ${ }^{7}$ Put differently, the argument is that the cost of equity simply reflects the firm's marginal product of capital (rather than the other way around). ${ }^{8}$ 
In order to tackle this complication we follow a simple way to decompose equity valuation into an 'investment opportunity' part and a 'financial advantage' part. The approach basically entails orthogonalizing $q$ against ex post observed 'future' investment (capital expenditure). We use this approach instead of simply controlling for average capital expenditure in the baseline regression in order to make better use of the time series dimension in the data, and in order to use the resulting variable more flexibly later on in interaction with other variables. Consider a standard investment- $q$ equation:

$$
\frac{I_{i t}}{K_{i t}}=\alpha+\beta \frac{V_{i t}}{K_{i t}}+\varepsilon_{i t}
$$

where $I$ is investment, $K$ is the capital stock, and $V$ is market value; $i$ and $t$ are firm and period subscripts; $V / K$ equals Tobin's $q$. Because the stock market is forward looking, we may lag the right hand side variables, or, equivalently, include investment with a one-period lead, to represent 'investment opportunities' rather than simultaneous actual investment. Now reverse the equation to obtain

$$
q_{i t}=a+b \frac{I_{i t+1}}{K_{i t}}+e_{i t}
$$

To the extent that future relative capital expenditure is a fair proxy for present investment opportunities, residuals from this regression are proxies for a 'purely financial' cost of equity factor. If used and found significant in a regression of the type represented by Equation 1, they point toward a mispricing-type explanation for the finance effect on FDI. (The fitted values from a regression of Equation 3, on the other hand, are proxies for an investment-opportunity factor inside the $q$-effect.) 'Mispricing' could entail overvaluation/'bubble' effects (Shleifer and Vishny (2003); Gilchrist et al. (2005)), and/or initial undervaluation/segmentation of the acquiring firm which has 
been 'corrected' - possibly as the result of conscious strategies by the firm to diminish information asymmetries, etc. (Oxelheim et al. (2001)).

One might surmise that, because FDI and acquisitions are also investments, we are stripping $q$ of all its predictive power on the dependent variable in Equation 1, but this is not necessarily the case. First, as argued in Section I, if any overvaluation (undervaluation) reflected in $q$ is somewhat correlated across firms within a source country, the residual valuation factor will represent a particular advantage (disadvantage) for undertaking foreign investment projects. It follows from an assumption of international financial market segmentation that local risk factors matter more for the pricing of stocks. This suggests to us that the mispricing component in those prices may be correlated within countries. Second, while we test the finance-sensitivity of foreign acquisitions, the correction for investment opportunities is made using relative capital expenditure. ${ }^{9}$ Therefore, we will not 'eat up' our own results; but even if we do to some extent, any remaining significant association between residual valuations and acquisition probability would just strengthen our case for a finance-FDI effect.

In summation, then, if mispricing is correlated within source countries (in line with a segmentation effect, for instance), residuals from regressions of Equation 3 are proxies for a particular financial advantage for undertaking FDI. In the absence of source-country-specific determinants of residual valuations, this factor just captures a firm-specific financial advantage - a pure cost of equity factor and therefore a matter of superior discount factor - for undertaking investment in general (or, possibly, acquisitions specifically), within or outside the firm's country of residence.

\section{Industry-specific financial drivers of FDI}


The possible analogy between the wealth-effect explanation for FDI of Froot and Stein (1991) and candidate motivations for a finance-FDI effect on the other hand, motivates a further exploration of the connection between firms' (financial) characteristics and the propensity to undertake cross-border investment. The arguments of Froot and Stein imply a greater exchange rate effect in certain industries, such as R\&D-intensive ones, where investments are more knowledge intensive, innovations may be more easily internalized within the $\mathrm{MNC}$, and financing constraints arising from information asymmetries are more pronounced. If there is a cost of capital effect working through a mechanism similar to that of the exchange rate, the industry specificity implication carries over to FDI-finance sensitivities, so that also financial factors are more important for firms in certain industries. A similar effect is implied by the result of, e.g., Rajan and Zingales (1998) that some industries are more dependent than others on external finance: for a firm which is heavily dependent on external finance, the relative effect on investment activity of having access to such finance is higher than for a less financially dependent firm.

The next step in the analysis is therefore to test whether this implication is supported by the data. We test Hypothesis 2 by interacting each of the included financial characteristics with a proxy for knowledge intensity and with industry dummy variables, and adding the interaction variables to the basic regression specification (Equation 1). If more knowledge-intensive firms have a higher FDI-finance sensitivity, coefficients for the financial/knowledge-intensity interaction variables should appear with equal sign as the stand-alone finance variables. We also expect that coefficients for the industry interaction variables will turn out significant with equal sign for more knowledge-intensive industries and/or with opposite sign as the stand-alone finance variables for less knowledge-intensive industries. 


\section{The role of source country financial development}

It has been suggested that investment may be differently linked to stock market valuations in different countries, depending on the country's level of financial development. For instance, Braun and Johnson (2006) juxtapose the 'active informant' view and the 'sideshow' view of investment- $q$ sensitivities.

The active informant view holds that the stock market is well able to predict 'fundamentals', and managers - who are at an informational disadvantage and cannot predict fundamentals as well as the collected view of the market - use the price signal to make investment decisions. Better developed stock markets produce better price signals and therefore, to the extent that managers are aware of the varying quality of stock market signals across countries, generate higher investment- $q$ sensitivities. The sideshow view, on the other hand, puts the market at an informational disadvantage, and the correlation between investment and stock prices is instead driven by the ability of managers and stock markets to predict fundamentals independently of each other. But given a constant, positive ability of managers to predict fundamentals, the correlation between investment and stock prices will be higher with increasingly efficient stock prices. Therefore, this view also predicts higher investment- $q$ sensitivities in better developed stock markets.

It is not clear that these arguments carry over to the finance-FDI effect. Indeed, if financial constraints are more binding and mispricing more prevalent in financially less developed markets, the 'cheap finance' explanation for FDI should be more important in these markets. Similarly, the proactive-financial-strategy story of a firm breaking out of a segmented and illiquid home market to rid itself of a financial disadvantage and 'internationalize' its cost of capital does not fit a firm originating in 
a country with a highly developed and internationally integrated domestic financial market. Our third main hypothesis is therefore that financial factor explanations for FDI are more important for firms originating in countries with less developed financial markets. To test Hypothesis 3, we use a similar strategy as in subsection C: we interact our financial variables with various measures of source country financial development, and add the interaction variables to the basic model specification. We expect that the interaction variables between financial factors and home-country financial development should enter with opposite-sign coefficients.

\section{E. Are the results robust to the inclusion of host-country determinants of FDI?}

So far we have considered only firm-level determinants of FDI. This may be called a 'partial-equilibrium' approach (with Blonigen (2005)), which may be motivated by the primary research question: which firms undertake FDI? However, a more 'general equilibrium'-oriented approach to FDI determination would also consider the effect of the target market. Indeed, the notion that a country - or, more generally, a jurisdiction - can be more or less attractive as host for direct investments underpins most FDI research. $^{10}$

A difficulty with testing firm-specific and host-country-specific determinants simultaneously is to translate the FDI decision to an econometric specification that reflects the decision in a realistic way. ${ }^{11}$ In order to distinguish between location determinants, it is necessary to include observations for each potential destination country; to distinguish between firm-specific determinants, it is necessary to include firmlevel observations. We get:

$$
A C Q_{i k}=\left\{\begin{array}{l}
1 \text { if } A C Q_{i k}^{*}>0 \\
0 \text { otherwise }
\end{array}\right.
$$


where

$$
A C Q_{i k}^{*}=\alpha+\beta^{\prime} F_{i}+\delta^{\prime} X_{i}+\phi^{\prime} H_{k}+\gamma^{\prime} C_{i k}+\varepsilon_{i k}
$$

$A C Q_{i k}^{*}$ is the size of acquisitions undertaken by firm $i$ in country $k$ (where $k$ is any country except the country of origin of $i), F_{i}$ and $X_{i}$ are firm-specific finance and other characteristics, as previously, $H_{k}$ are factors specific to host country $k$ (the target firm's home market), and $C_{i k}$ are control variables which may vary over firms or across countries.

The total number of observations for this regression is $N=I \times K$, where $I$ is the number of firms, and $K$ is the number of potential destination countries. In other words, for each of the $I$ firms, we have separate observations for each possible destination country. It is not clear that these observations are independent. Specifically, it is not clear that firm $i$ 's decision not to invest in country $k$ is independent of its decision not to invest in country $m$. If it is not, we end up with a large number of zeros on the left hand side of Equation 4 that are correlated within cross-section units. Moreover, the number of potential destination countries is, presumably, every single country in the world. But the number of total observations in a regression of Equation 4 increases exponentially with the inclusion of each additional country, which makes it intractable and increases the serial correlation problem just mentioned. On top of all this, if the advantages of investing in a particular destination country arise because of finance-related reasons, this should already be accounted for in our firm-level regressions.

For these reasons, we argue that the regressions on firm-specific factors alone, outlined in subsections II.A through D.II, give a better account of the investment decision process - perhaps not a full account, but a more realistic one than that represented by Equation 4. However, in order to complete the picture, and to check robust- 
ness, we still go ahead with the inclusion of host-country factors. The analysis is conducted in a stepwise manner.

The number of included possible host countries must, as mentioned, be limited due to various practical considerations. First, we eliminated the countries that did not receive any direct investment from the firms in our sample. Second, several of the remaining countries were eliminated because of lack of adequate data. The nonrandomness of this process of elimination introduces the risk of sample selection bias as regards the country-specific variables. To take this into consideration, we adopt the standard Heckman (1979) approach of first estimating a simple probit model of the selection process. From this estimation we obtain a country-specific variable, the inverse Mills-ratio (typically termed 'lambda'), which - by proxying for the probability of being included in the sample in the first place - corrects Model 4 for the potential selection bias. The selection model takes the form:

$$
S E L_{j}=\alpha+\beta^{\prime} Z_{j}+\varepsilon_{j}
$$

where $S E L_{j}$ takes on unit value if country $j$ was selected as a possible destination country for investment in the final regressions, and zero otherwise. The countries $J$ are a random sample drawn from the population of all possible destination countries, and $Z_{j}$ is a vector of country characteristics believed to correlate with the decision to include the country in the final sample of possible destination countries.

The next step is to estimate the full model, including both firm-specific and destination-country-specific characteristics, as described by Equation 4. The model is estimated in a pooled cross-section setting in order to account for the panel-like structure of the dataset that follows from considering variation in two dimensions - the firm (cross-section) dimension, and the host-country dimension. 


\section{F. Further robustness tests: the number of acquisitions undertaken}

Our dataset allows us to identify not only which firms in the sample made a foreign acquisition, but also how many foreign acquisitions each of these firms made. Although we are primarily interested in determining which firms made any foreign acquisitions, we make use of this information for a final alternative model specification which provides us with a further robustness test of the results obtained. The test entails performing negative binomial regressions of the form:

$$
N O A C Q_{i}=\alpha+\beta^{\prime} F_{i}+\delta^{\prime} X_{i}+\gamma^{\prime} C_{i}+\varepsilon_{i},
$$

where $N O A C Q_{i}$ is the number of acquisitions made by firm $i$, and the right hand side is defined as previously. Expectations on the coefficients are also in analogy with Equation 1.

\section{Definitions and data set}

In this section we describe the variables used (for a detailed listing, see the data appendix) and their sources, and provide some summary sample statistics.

\section{A. Variable definitions and data sources}

The methodology described in the previous section was applied to a sample of Eurozone firms, and most of the variables used are based on financial statement items for these firms from between 1996 and 2001 as reported in the COMPUSTAT Global Industrial Database. Using Eurozone firms presents a particular advantage because it minimizes the risk of mixing up the financial-variable effect with a possible exchange rate effect (which is easy enough to control for with country-level data, but considerably more cumbersome with firm-level data), but still permits us to explore the effect of variation in certain source country characteristics, as outlined in section II. 
The dependent variable (the foreign acquisitions dummy) comes from the Thomson Mergers and Acquisitions Database, which contains data on acquisitions worldwide. The COMPUSTAT firm-level data were matched with the Thomson data, which had previously been filtered to contain only cross-border deals completed in 2000, where the acquirer was a firm with EMU-country origin. COMPUSTAT firms that appeared in the filtered Thomson data were flagged for the dependent variable.

The financial variables used are proxies for the cost of equity, cost of debt, and credit rating, and an indicator cross-listing variable. The main proxy for the cost of equity is Tobin's $q$, i.e. the market value over the book value of total assets. This measure of firm valuation is used extensively in the literature and was considered to be the most representative measure. As an alternative proxy for the cost of equity capital we use the sales/price ratio. We chose to relate price to sales rather than to earnings, since negative $\mathrm{p} / \mathrm{e}$ or $\mathrm{e} / \mathrm{p}$ ratios have no sensible interpretation, and to put sales in the numerator rather than in the denominator in order to avoid the skewness and outlier problem that occurs when some firms in the sample have very low sales (see, e.g., Smart and Zutter (2003)).

The cross-listing dummy takes on unit value for firms that cross-listed their stocks on the NYSE, on NASDAQ, or on the London Stock Exchange during 19962000. The variable was constructed using information in fact books and reports from each of these three stock exchanges.

The cost of debt is simply the firm's actual interest expenditure divided by its total liabilities, as reported in financial statements. The expected effect of the cost of debt on the dependent variable is, however, ambiguous. On the one hand, a reduction in the overall cost of capital through reduced cost of debt would, ceteris paribus, increase the level of investment in general, indicating a negative relationship. On the 
other hand, increased leverage may be a way to finance acquisitions, but will also in general tend to push up the credit risk premium inherent in the cost of debt, indicating a potential positive relationship between acquisition likelihood and cost of debt.

As a proxy for firms' credit rating we used Altman's Z"'-score, which is a continuous variable constructed from a number of balance-sheet items to reveal the firm's credit risk (see Altman (2002)). In the absence of consistent and comparable series of actual ratings from international credit rating agencies, this provides us with a secondbest solution. The basic conjecture is that an improved credit rating should increase acquisition probability, but the variable may be correlated with other cost of capital measures to the extent that the market uses 'ratings' as a basis for determining the rate of return at which to provide financing and/or to the extent that market prices enter into the production of ratings (this is indeed the case for the Z"-score, see sub-section III.B). As a final finance-related variable, we included free cash flow to proxy for internal financing (Stein (1997)).

Variables for 'traditional' FDI determinants were chosen on the basis of the results of earlier empirical studies, or of surveys thereof (see e.g. Cantwell and Narula (2003); Blonigen (2005)). They include firm size, proxies for the importance of knowledge and capital intensity (intangible assets as a share of total assets, and the share of fixed capital), and profitability (return on assets). Firm-level control variables are industry and source country dummies.

Source-country-specific variables are primarily various measures of financial development. We used three measures suggested by Rajan and Zingales (2003): stock market capitalization over GDP, net equity issues over gross fixed capital formation, and private sector credit over GDP. Sources for these variables were IMF International Financial Statistics (GDP, investment, and credit) and Eurostat (stock market 
capitalization). Net equity issues were proxied as the year-on-year change in stock market capitalization, corrected for the change in stock prices as measured by Datastream's overall market price index for each country. The data were collected and the variables calculated for each of the years 1996-2000, and then averaged. In addition to the above-mentioned three financial-development variables, we used the shareholder rights and creditor rights indices of La Porta et al. (1998).

The variables for host-country FDI determinants used in the 'full-size' model described in subsection II.E are target market size, income level, production costs (proxied by average manufacturing wages), the rate of corporate income taxation, and indices for the level of corruption, and legal and political accountability. These are broadly in conformity with Blonigen's (2005) listing of typical host-country effects on FDI. The data are from IMF's International Financial Statistics or the World Bank's World Development Indicators (GDP, population, and wage level), PricewaterhouseCoopers (2000) (corporate taxes), Transparency International (transparency index), and from Kaufmann et al. (2003) (index of political system integrity). Definitions of all the variables used appear in the data appendix.

\section{B. Basic sample statistics}

The total number of firms in the sample was 1459 . All firm-specific variables were available for 1373 of these firms. Descriptive statistics for these variables appear in Table I. The finance-related variables are also divided between sample firms that undertook FDI and firms that did not, and tested non-parametrically for significant differences in distribution. As shown by these tests, firms that undertook FDI exhibit significantly different median values for four of the five included finance-related variables, as compared to non-FDI firms. In all cases, the differences are in the expected 
direction (international acquirors have higher $q$, lower sales/price ratio, higher free cash flow, and higher 'credit rating'). These observations serve as a preliminary indication of the potential explanatory power of financial factors.

[Insert Table I]

[Insert Table II]

Table II shows that correlations between finance-related and other firmspecific variables are often statistically significant but typically very low, with the exception of free cash flow and the return on assets. Within the group of finance-related variables, Tobin's $q$ and the Z"-score are rather highly positively correlated. We therefore initially avoid mixing free cash flow and ROA, and $q$ and Z", respectively, in the same regressions.

\section{Results}

\section{A. Baseline regression results}

Table III reports results from the baseline regressions (equation 1). Models 1 and 4 use only the finance-specific variables with the two proxies for cost of equity, and the full set of source-country and industry dummies. In specifications 2 and 5, traditional firm-level FDI determinants are substituted for the control variables. Models 3 and 6, finally, use both financial and non-financial determinants and industry control dummies (whereas the apparently unimportant source-country dummies were left out). The results from all the models confirm that several finance-specific factors affect the propensity to make foreign investments. 
The most relevant finance factors are those directly related to access to competitively priced equity (as indicated both by the cross-listing variable and the equity valuation proxies). In statistical terms, cost of equity and cross-listing are both highly significant. In economic terms, the effect of the cost of equity is small; for example, using the rule of thumb of dividing probit coefficients by 2.5 to arrive at approximate marginal probabilities (see Wooldridge (2002)), the coefficient estimates for Tobin's $q$ indicate that a unit increase in $q$ raises the probability of foreign acquisitions by around 5 percent. The marginal increase in acquisition probability of recent crosslisting, on the other hand, is substantial (upward of 20 percent using a similar approximation).

The cost of debt is statistically insignificant and coefficient estimates are unstable. The effects of the two additional finance-related variables - internal financing and credit worthiness - appear to be of relatively minor importance. The coefficients for the first of these are statistically insignificant. The latter, which was excluded from models 1-3 due to its high correlation with Tobin's $q$, appears statistically significant with the right sign in the last two specifications of Table III, but the coefficients indicate an effect which is smaller in magnitude over the distribution of this variable than that of the directly equity-related variables.

As regards traditional FDI determinants, firm size and high knowledge intensity (as proxied by the share of intangible assets) increase the probability to invest abroad, as expected. The coefficients are economically and statistically significant and highly stable over the different specifications. Coefficients for industry dummies, finally, reinforce the impression that firms in sectors with higher knowledge intensity (such as durables, electronics, and services) are more likely to invest abroad. 
Wald tests of specifications with and without the financial variables included indicate a very strong incremental explanatory power of the included financial variables. We infer from these results that financial factors clearly do matter for the decision to undertake a cross-border acquisition.

[Insert Table III]

\section{B. Correcting for investment opportunities}

The results of the panel regressions on Equation 3, shown in Table IV, indicate that both Tobin's $q$ and the sales/price ratio are highly significant predictors of one-yearahead relative capital expenditure. The residuals from these regressions were averaged over the sample period for each of the sample firms and the resulting averages constitute the 'Residual $q$ ' and 'Residual sales/price' measures used throughout the remainder of the paper.

[Insert Table IV]

Table V shows these measures applied to the baseline regression model. Specifications 1 and 2 are identical to models 1 and 3 in Table III; specifications 3 and 4 are identical to Table III's models 4 and 6; all with the exception of the definition of the equity valuation proxies. The results are strikingly similar (with the perhaps somewhat surprising - given the consistency of the other results - exception of the marginal statistical insignificance of the cross-listing dummy in specification 2), and strongly suggest the maintained importance of the equity-related financial variables, even when corrected for a general investment-opportunity factor. 
[Insert Table V]

\section{Financial effects of knowledge intensity and industry}

Table VI provides further insight into the effects of financial characteristics on foreign acquisition likelihood. In particular, it shows for which firms these characteristics matter. Here we have interacted each of the financial variables (except the crosslisting dummy) with the proxy for knowledge intensity (intangible assets) and with the industry control dummies, since - as explained in sub-section II.C, some conceivable mechanisms by which finance can influence FDI indicate that finance (particularly the cost of equity) should be more important in more knowledge-intensive industries.

This seems indeed to be the case. Looking first at columns 1 and 2, we see that both equity valuation measures lose their statistical significance as stand-alone variables, whereas the joint effect of equity costs and intangibles is very strong for both measures. It would appear, therefore, that the finance-FDI effect primarily obtains for firms with above-average knowledge intensity. Interactivity with industry dummies reveals no similar pattern of increased finance-sensitivity for knowledge-intensive industries, but indicates lower sensitivities for certain semi-heavy industries when $q$ is used to proxy equity costs. This result would be in line with expectations insofar as these industries are less knowledge-intensive than the average sample firm.

In contrast, the explanation for the indeterminate effect of overall debt costs does not seem to lie in industry-specific effects. Two industry/interest-rate interaction variables turn up significant with large positive coefficients - both relatively highknowledge industries (electronics and services). Knowledge intensity overall, how- 
ever, does not interact significantly with debt costs. Credit ratings, finally, show an interaction pattern similar to that of equity costs: the share of intangibles reinforces the already positive effect of credit worthiness on FDI probability (and vice versa both credit rating and intangibles lose their statistical significance as stand-alone variables in this specification), whereas no systematic pattern of interaction with industry dummies emerges.

[Insert Table VI]

\section{The effect of source-country financial development}

The results of interacting financial FDI determinants with home-country financial development are reported in Table VII. The results by and large confirm the arguments advanced in sub-section II.D - which are, in turn, broadly in line with the wealth effect/arbitrage explanation for the finance-FDI effect (Froot and Stein (1991); Blanchard et al. (1993); Baker et al. (forthcoming)), as well as with the financialinternationalization effect (Oxelheim et al. (2001)) - that finance matters more for firms from financially less developed economies. As indicated by previous specifications, it is mostly equity-related factors that matter. The results are somewhat less convincing than previously, however; indeed, the effect is absent or only marginally significant when the residual sales/price ratio is used to proxy the cost of equity and when equity issues over aggregate investment is used as the sole measure of stockmarket development. Also, the (marginally significant) positive interaction between equity valuation and shareholder rights in specification 1 is somewhat at odds with the 'financial disadvantage' story, but may be a consequence of lower reliance on equity in countries with poorer protection for shareholders (and consequently a lower equity- 
FDI effect in those countries). Among credit-related factors, we find that having a high creditworthiness has more of an impact on foreign acquisition likelihood for firms resident in countries where creditors have less legal protection. This finding corresponds well to the advanced hypothesis.

[Insert Table VII]

\section{E. Controlling for host-country FDI determinants}

Table VIII reports a number of alternative specifications of the target country selection probit model. (Descriptive statistics and correlations for the included variables are reported in the data appendix.) As expected, the results are robust to alternative specifications. The sample-selection corrections (lambdas) finally used in the pooled regressions reported in Table IX are those implied by model 2 in Table VIII, based both on its middle-of-the-road coefficient estimates, the belief that Population and Income are the key variables, and the log-likelihood statistics.

[Insert Table VIII]

Regressions on both acquirer and target-country characteristics reinforce the conclusions and overall impressions of previous results. Qualitatively, the results, reported in Table IX, are almost identical to the results in Tables III and V as regards firmspecific regressors. The coefficient estimates, however, are smaller. This is not surprising, since the coefficients now represent the probability that a particular firm will invest in a particular country (rather than the probability that the firm will make a foreign investment anywhere). 
In addition, several target-country regressors turn out to be important explanatory factors, particularly market size, as measured by GDP or population, and absence of political risk, but also the income level is usually significant (and negative as expected). Overall, this suggests that both market seeking in other politically and economically mature countries and restructuring/production planning are viable motives for European firms' international acquisitions.

Making use of the pooled cross-sectional character of the dataset, we detect significant firm-level and country-level contributions to the variance of the errors (not reported). The inclusion of the linear 2-way random effects specifications (Models 4 and 5 in Table IX) can be seen as a way of controlling for this. With this specification, equity valuation, when measured as residual $q$ turns (marginally) insignificant, whereas the residual sales/price ratio and the cross-listing dummy remain highly significant. The linear models highlight the small magnitude of the coefficients (since they can be interpreted directly in terms of probabilities); ${ }^{12}$ however, as previously mentioned, the coefficients now represent the probability that a particular firm will invest in a particular country, which makes them somewhat difficult to interpret as regards the firm-level regressors. On the whole, however, the qualitative similitude (with respect to these firm-level regressors) of these results with previous firm-levelonly specifications indicates that our previous results are indeed robust to the inclusion of target-country FDI determinants.

Finally, the selection bias correction factor turns out significant in only one of the specifications. Exclusion of the 'lambdas' does not alter the results to any significant extent. 
[Insert Table IX]

\section{F. Results of count regressions}

The last robustness tests are the count regressions on the number of acquisitions undertaken. These tests confirm the positive effects of equity valuation and credit worthiness on FDI, but the cross-listing dummy is now not statistically significant. In this regard, it mirrors results of some previous specifications, whereas other specifications have tended rather to 'favor' cross-listing over equity costs. In this, these last tests highlight the difficulty of pin-pointing the exact mechanism by which the finance-FDI effect occurs: a wealth-effect/mispricing explanation would emphasize the equity cost component, whereas a 'proactive' explanation would (perhaps) afford a greater role to the more unequivocally strategic cross-listing variable.

[Insert Table X]

\section{Summary and concluding remarks}

In this paper we have argued that the standard models for explaining multinational firms' foreign direct investment give insufficient heed to financial motives. In particular, we showed that the assumption of (at least partial) international capital market segmentation opens up a number of possible mechanisms for a direct cost-of-capital effect on firms' incentives to undertake foreign investment projects in general, and perhaps foreign acquisitions in particular.

Based on binary-response regressions on a sample of European non-financial firms and their foreign acquisitions, we found strong evidence in favor of an independent equity-valuation effect on FDI. Key equity-related financial variables turned 
out to be equally important as, or more important than, several more traditional firmlevel determinants of foreign investment. Specifically, our results show that firms with more highly valued equity, and firms which have recently cross-listed their equity on a large and liquid stock exchange, are more likely to make foreign acquisitions. These results are qualitatively robust to alternative model specifications and largely independent of the measure for equity costs used. More importantly, they remain after these measures have been corrected for a general investment-opportunity effect. The effects on foreign acquisition likelihood of financial characteristics not directly related to equity, however, appear to be marginal. The effects of debt costs and internal financing are, overall, indeterminate, and usually statistically insignificant. Our proxy for credit worthiness, on the other hand, is often statistically significant, but typically small in economic terms.

In addition, we found that financial determinants are more important for firms originating in countries that are relatively less financially developed - a finding consistent with hypotheses advanced. Also in line with arguments made in the paper is the finding that financial motives for FDI are significantly stronger for more knowledge-intensive firms. However, we found only mixed evidence of variation in FDIfinance sensitivity by industry more generally.

Our conclusion is that an explicit consideration of firms' financial positions is necessary to explain cross-border investment. However, more work is needed on identifying the exact mechanism whereby the finance-FDI effect occurs. We have noted at several instances in the paper the difficulty of pin-pointing that mechanism, and our results are consistent with several candidate rationalizations for the effect that have appeared in, or can be derived from, the literature. These include a wealth/arbitrage effect (Froot and Stein (1991); Baker et al. (forthcoming)), and a proactive-financial- 
strategy effect (Oxelheim et al. (2001)). As briefly suggested in the paper, the question of by what mechanism the finance-FDI effect occurs is linked to the mode of investment. Since it is possible that the finance effect is particularly prevalent for foreign acquisitions, more work is needed to determine whether the effect is similar for other types of investment. As shown by, for instance, Shleifer and Vishny (2003), the question of investment mode, finally, is not separated from that of payment mode. We would expect that firms that wish to exploit a favorable equity valuation by investing would do so by paying with equity. In the context of foreign direct investment and cross-border acquisitions, this too remains to be researched. 
Appendix: Variable definitions and additional statistics

[Insert Tables A1-A6] 


\section{References}

Aliber, Robert Z., 1970, A Theory of Foreign Direct Investment, in Charles P. Kindleberger, ed.: The International Corporation (MIT Press, Cambridge, MA.).

Altman, Edward I., 2002, Revisiting credit scoring models in a Basel II environment, in Michael Ong, ed.: Credit Ratings: Methodologies, Rationale and Default Risk (Risk Books, London).

Bain, Joe S., 1956. Barriers to New Competition (Harvard University Press, Cambridge, MA.).

Baker, Malcolm, C. Fritz Foley, and Jeffrey Wurgler, forthcoming, Multinationals as arbitrageurs: The effect of stock market valuations on foreign direct investment, Review of Financial Studies.

Baker, Malcolm, Jeremy C. Stein, and Jeffrey Wurgler, 2003, When Does the Market Matter? Stock Prices and the Investment of Equity-Dependent Firms, Quarterly Journal of Economics 118, 969-1006.

Blanchard, Olivier, Changyong Rhee, and Lawrence Summers, 1993, The Stock Market, Profit, and Investment, Quarterly Journal of Economics 108, 115-136.

Blonigen, Bruce A., 1997, Firm-Specific Assets and the Link Between Exchange Rates and Foreign Direct Investment, American Economic Review 87, 447465.

Blonigen, Bruce A., 2005, A Review of the Empirical Literature on FDI Determinants, Atlantic Economic Journal 33, 383-403.

Bodnar, Gordon M., Bernard Dumas, and Richard C. Marston, 2003, Cross-Border Valuation: The International Cost of Equity Capital, NBER Working Paper 10115. 
Braun, Matías, and Christian Johnson, 2006, Where Does the Market Matter? Stock Prices and Investment around the World, Paper presented at the FMA Annual Meeting, Salt Lake City, UT, October, 2006.

Brealey, Richard A., Ian A. Cooper, and Evi Kaplanis, 2005, A test of international equity market integration using evidence from cross-border mergers, Institute of Finance Working Paper 433, London Business School.

Buckley, Peter J., and Mark Casson, 1976. The Future of the Multinational Enterprise (Homes \& Meier, London).

Cantwell, John, and Rajneesh Narula, 2003. International Business and the Eclectic Paradigm (Routledge, London).

Caves, Richard E., 1971, International Corporations: The Industrial Economics of Foreign Investment, Economica 56, 279-293.

Caves, Richard E., 1980, Investment and location policies of multinational companies, Schweizerische Zeitschrift für Volkswirtschaft und Statistik 116, 321-327.

De Santis, Roberto A., Robert Anderton, and Alexander Hijzen, 2004, On the determinants of Euro area FDI to the United States: The Knowledge-Capital Tobin's Q framework, Working Paper 329, European Central Bank.

Dunning, John H., 1977, Trade, location of economic activity and the MNE: A search for an eclectic approach, in Bertil Ohlin, Per-Ove Hesselborn, and Per M. Wijkman, eds., The International Allocation of Economic Activity (Macmillan, London).

Dunning, John H., 1988. Explaining International Production (Unwin Hyman, London).

Dunning, John H., 1993. Multinational Enterprises in the Global Economy (Addison Wesley, Wokingham Berks). 
Fazzari, Steven M., R. Glenn Hubbard, and Bruce C. Petersen, 1988, Financing Constraints and Corporate Investment, Brookings Papers on Economic Activity 1, 141-206.

Foerster, Stephen R., and G. Andrew Karolyi, 1999, The Effects of Market Segmentation and Investor Recognition on Asset Prices: Evidence from Foreign Stock Listing in the United States, Journal of Finance 54, 981-1013.

Froot, Kenneth A., and Jeremy C. Stein, 1991, Exchange Rates and Foreign Direct Investment: An Imperfect Capital Markets Approach, Quarterly Journal of Economics 106, 1191-1217.

Gilchrist, Simon, Charles P. Himmelberg, and Gur Huberman, 2005, Do stock price bubbles influence corporate investment?, Journal of Monetary Economics 52, $805-827$.

Heckman, James J., 1979, Sample Selection Bias as a Specification Error, Econometrica $47,153-161$.

Horstmann, Ignatius J., and James R. Markusen, 1989, Firm-specific Assets and the Gains from Direct Foreign Investment, Economica 56, 41-48.

Hymer, Stephen H., 1976. The International Operations of National Firms: A Study of Foreign Direct Investment (MIT Press, Cambridge, MA.).

Karolyi, G. Andrew, and René M. Stulz, 2003, Are Assets Priced Locally or Globally?, in George M. Constantinides, Milton Harris, and René M. Stulz, eds., Handbook of Economics and Finance (Elsevier, Amsterdam).

Kaufmann, Daniel, Aart Kraay, and Massimo Mastruzzi, 2003, Governance Matters III: Governance Indicators for 1996-2002, Policy Research Working Paper 3106, The World Bank. 
Klein, Michael W., and Eric S. Rosengren, 1994, The real exchange rate and foreign direct investment in the United States: Relative wealth vs. relative wage effects, Journal of International Economics 36, 373-389.

Kogut, Bruce, 1985, Designing Global Strategies: Profiting from Operational Flexibility, Sloan Management Review 27, 27-38.

Kogut, Bruce, and Sea-Jin Chang, 1991, Technological Capabilities and Japanese Foreign Direct Investment in the United States, Review of Economics and Statistics 73, 401-413.

Kogut, Bruce, and Nalin Kulatilaka, 1994, Operating Flexibility, Global Manufacturing, and the Option Value of a Multinational Network, Management Science 40, 123-139.

La Porta, Rafael, Florencio López-de-Silanes, Andrei Shleifer, and Robert W. Vishny, 1998, Law and Finance, Journal of Political Economy 106, 1113-1155.

Lombardo, Davide, and Marco Pagano, 2006, Legal Determinants of the Return on Equity, in Lars Oxelheim, ed., Corporate and Institutional Transparency for Economic Growth in Europe (Elsevier, Amsterdam).

Makino, Shige, Cung-Ming Lau, and Rhy-Song Yeh, 2002, Asset-Exploitation Versus Asset-Seeking: Implications for Location Choice of Foreign Direct Investment from Newly Industrialized Economies, Journal of International Business Studies 33, 403-421.

Markusen, James R., 1984, Multinationals, multi-plant economies, and the gains from trade, Journal of International Economics 16, 205-226.

Miller, Darius P., 1999, The market reaction to international cross-listings: evidence from Depositary Receipts, Journal of Financial Economics 51,103-123. 
Modén, Karl-Markus, and Lars Oxelheim, 1997, Why issue equity abroad? - Corporate efforts and stock markets responses, Management International Review $37,223-241$.

Morck, Randall, Andrei Shleifer, and Robert W. Vishny, 1990, The Stock Market and Investment: Is the Market a Sideshow?, Brookings Papers on Economic Activity $2,157-215$.

Myers, Stewart C., and Nicholas S. Majluf, 1984, Corporate Financing and Investment Decisions when Firms Have Information that Investors Do not Have, Journal of Financial Economics 13, 187-221.

Oxelheim, Lars, Trond Randøy, and Arthur Stonehill, 2001, On the treatment of finance-specific factors within the OLI paradigm, International Business Review 10, 381-398.

Oxelheim, Lars, and Trond Randøy, 2003, The impact of foreign board membership on firm value, Journal of Banking and Finance 27, 2369-2392.

Pagano, Marco, Ailsa Röell, and Josef Zechner, 2002, The Geography of Equity Listing: Why Do Companies List Abroad?, Journal of Finance 57, 2651-2694.

PricewaterhouseCoopers, 2000. Corporate Taxes: Worldwide Summaries 1999-2000 (Wiley, Hoboken, NJ.).

Rajan, Raghuram G., and Luigi Zingales, 1998, Financial Dependence and Growth, American Economic Review 88, 559-586.

Rajan, Raghuram G., and Luigi Zingales, 2003, The Great Reversals: The Politics of Financial Development in the $20^{\text {th }}$ Century, Journal of Financial Economics 69, 5-50.

Rugman, Alan M., 1981. Inside the Multinationals: The Economics of Internal Markets (Columbia University Press, New York, NY.) 
Shleifer, Andrei, and Robert W. Vishny, 2003, Stock market driven acquisitions, Journal of Financial Economics 70, 295-311.

Smart, Scott B., and Chad J. Zutter, 2003, Control as a motivation for underpricing: a comparison of dual and single-class IPOs, Journal of Financial Economics 69, 85-110.

Stein, Jeremy C., 1997, Internal Capital Markets and the Competition for Corporate Resources, Journal of Finance 52, 111-133.

Sundaram, Anant K., and Dennis E. Logue, 1996, Valuation effects of foreign company listings on U.S. exchanges, Journal of International Business Studies 27, 66-88.

Svaleryd, Helena, and Jonas Vlachos, 2005, Financial markets, the pattern of specialization, and comparative advantage: Evidence from OECD countries, European Economic Review 49, 113-144.

Tolmunen, Pasi, and Sami Torstila, 2005, Cross-Listings and M\&A Activity: Transatlantic Evidence, Financial Management 34, 123-142.

Wesson, Thomas J., 1993. An Alternative Motivation for Foreign Direct Investment, PhD dissertation (Harvard University, Cambridge, MA.).

Wooldridge, Jeffrey M., 2002. Econometric Analysis of Cross Section and Panel Data (MIT Press, Cambridge, MA.). 


\section{Notes}

\footnotetext{
${ }^{1}$ Such as size, monopoly power, better resource capability and usage (Bain (1956)); economies of multi-plant structures and common ownership (Caves (1980)); and advantages of multinationality that enable MNCs to capitalize on differences in factor endowments and other local market conditions.
} (Kogut (1985)).

${ }^{2}$ Under the assumption of efficient and internationally integrated financial markets, of course, any firm can source its funding anywhere, regardless of country of residence, and so no firm will have a financial advantage over any other. Moreover, exchange rates will have no effect on FDI, because any effect of exchange rates on the price of a foreign investment will have a reverse effect when the investing firm exchanges the returns on the investment back to its home currency: exchange rate fluctuations will not have any net effect on the relationship between the investment and its returns, and so will not present an advantage for foreign firms over domestic firms or vice versa.

${ }^{3}$ A case in point, Dunning (1993) considers financial market imperfections and recognizes that firms' propensity to own foreign income-generating assets may be influenced by financial and exchange rate variables. He also discusses a 'financial asset advantage' which refers to "firms' superior knowledge of, and access to foreign sources of capital", but essentially finds this advantage to be a by-product of the size, efficiency and knowledge capital of the firm.

${ }^{4}$ For example, Bodnar et al. (2003) conclude that "[f]or all countries, it is clear that [...] local-country risk premium dominates the pricing. This is a striking empirical fact [...]" (p. 24). Similar conclusions may be found in surveys of the empirical literature, such as Karolyi and Stulz (2003). Even the most recent empirical studies fail to find support for a far-gone international integration in capital markets. For instance, Lombardo and Pagano (2006) construct a model of international equity markets, which produces clear implications for parameter estimates depending on whether the markets are integrated or not; when put to the data, the hypothesis of international equity integration can be clearly rejected regardless of time period, geographical coverage, and proxy variables used. Brealey et al. (2005) study changes in betas from cross-border mergers, and find that the observed changes are only consistent with the assumption of equity market segmentation. The inevitable conclusion is that firms must use local pricing models also to discount foreign investment projects, because their cost of equity is determined in the (segmented) market where it is raised, i.e., the home market. 


\footnotetext{
${ }^{5}$ For instance, in Rajan and Zingales (1998), financial development reduces the cost of external finance, which causes industries that are particularly dependent on external finance to grow faster in countries with well-developed financial markets; in a similar vein, Svaleryd and Vlachos (2005) find that finance can be treated as a comparative advantage, and is a robust determinant of industrial specialization between different countries.
}

${ }^{6}$ Blonigen's (1997) exchange rate effect largely builds on an alternative view on FDI than that represented by traditional theories. The latter all presume that firms have firm-specific intangible assets which can be exploited by FDI, but empirically this is not always the case. This observation has spawned increased attention to asset-seeking (as opposed to asset-exploiting) FDI (Kogut and Chang (1991); Wesson (1993)). Asset-seeking and asset-exploiting motivations for FDI are not necessarily mutually exclusive: for instance, Makino et al. (2002) found that Taiwanese firms were more likely to engage in asset-seeking FDI in developed countries if they were already relatively technologically advanced. Unlike Froot and Stein's (1991) wealth effect, Blonigen's exchange rate effect does not 'automatically' translate into a finance effect since it builds directly on the valuation effects of exchange rate changes between the acquisition and return currencies. Without exchange rate changes, there are no such valuation effects. However, Blonigen's theory is consistent with a general discount-factor-type effect under financial market segmentation. But more than that, if mispricing is local (rather than idiosyncratic), and overvaluation is correlated with real exchange rate appreciation (e.g. through portfolio investment inflows), then Blonigen's exchange rate effect will coincide with a general discount-factor effect. Of course, both imply that foreign and local firms value the acquired local asset differently. ${ }^{7}$ Even if we control for 'fundamentals' - in this case traditional firm-level FDI determinants - in the baseline regression, the case can be made as long as our proxies for these fundamentals are not perfect. ${ }^{8}$ Blanchard et al. (1993) note that $q$ and investment will move together if markets value the firm at its 'fundamental' value, but that in this case " $q$ will not cause investment in any useful sense" (p. 116). If, on the other hand, markets and managers value the firm's investment opportunities differently, then the stock market may drive investment. This could be due to information asymmetries between markets and managers, to speculative bubbles, or to valuation 'fads' causing misalignments of stock prices from 'fundamentals'.

${ }^{9}$ This is the measure traditionally used for estimating investment- $q$ relationships, and consequently the one used in this paper as well (see data appendix for exact definitions and sources). 
${ }^{10}$ For example, Dunning's (1977) OLI framework affords a prominent position to 'Location' determinants of FDI; the 'new economic geography' is primarily concerned with explaining the spatial pattern of direct investment flows; etc.

${ }^{11}$ Cf. Blonigen's (2005) contention that the emphasis in the empirical FDI literature on partialequilibrium explanations for FDI is "due to the difficulty of building a model that accounts for general equilibrium features that is tied back to microeconomic decision making" (p. 392).

${ }^{12}$ On the other hand, the linear specifications have the disadvantage that they assume a constant marginal probability (of undertaking foreign investment, in this case). 


\section{Table I. Descriptive statistics, firm-specific variables}

The table reports summary statistics for the included firm-level variables. Summary statistics for financial variables are reported separately for firms that undertook cross-border acquisitions (acq.) and those that did not (non-acq.), as well as for all sample firms (all). The 'Test' column reports the Wilcoxon/Mann-Whitney rank-based test statistic for the null hypothesis that acq. and non-acq. groups have equal distributions around the median. $* *$ and $* * *$ indicate rejection of the null hypothesis of equal medians at the $5 \%$ and $1 \%$ significance level, respectively.

\begin{tabular}{|c|c|c|c|c|c|c|c|c|}
\hline & Firm group & Mean & Std. dev. & Median & Test & Min. & Max. & Obs. \\
\hline \multicolumn{9}{|l|}{ Financial variables } \\
\hline \multirow[t]{3}{*}{ Tobin's $q$} & All & 1.66 & 1.31 & 1.27 & & 0.44 & 17.0 & 1392 \\
\hline & Acq. & & & 1.52 & & & & \\
\hline & Non-acq. & & & 1.23 & $6.64 * * *$ & & & \\
\hline \multirow[t]{3}{*}{ Sales/price } & All & 2.98 & 3.52 & 1.84 & & 0.00 & 30.7 & 1389 \\
\hline & Acq. & & & 1.32 & & & & \\
\hline & Non-acq. & & & 2.07 & $5.35 * * *$ & & & \\
\hline \multirow[t]{3}{*}{ Cost of debt } & All & 0.027 & 0.015 & 0.026 & & 0.000 & 0.125 & 1452 \\
\hline & Acq. & & & 0.026 & & & & \\
\hline & Non-acq. & & & 0.026 & 0.016 & & & \\
\hline \multirow[t]{3}{*}{ Internal financing } & All & 0.004 & 0.073 & 0.012 & & -0.918 & 0.594 & 1421 \\
\hline & Acq. & & & 0.018 & & & & \\
\hline & Non-acq. & & & 0.011 & $2.68^{* * *}$ & & & \\
\hline \multirow[t]{3}{*}{ Credit rating } & All & 4.07 & 3.81 & 3.16 & & -16.0 & 31.6 & 1373 \\
\hline & Acq. & & & 3.35 & & & & \\
\hline & Non-acq. & & & 3.07 & $2.35^{* *}$ & & & \\
\hline \multicolumn{9}{|l|}{ Other variables } \\
\hline Size & & 5.88 & 1.88 & 5.68 & & 1.34 & 11.7 & 1457 \\
\hline Intangibles & & 0.070 & 0.10 & 0.027 & & -0.002 & 0.84 & 1454 \\
\hline Capital intensity & & 0.31 & 0.19 & 0.27 & & 0.00 & 0.97 & 1456 \\
\hline Sales/employee & & 5.24 & 0.71 & 5.19 & & 0.65 & 7.79 & 1418 \\
\hline ROA & & 0.079 & 0.079 & 0.079 & & -0.71 & 0.60 & 1455 \\
\hline \multicolumn{9}{|l|}{$\underline{\text { Dummy variables }}^{\mathrm{a}}$} \\
\hline Acquisition & & & & & & & & 270 \\
\hline Cross-listing & & & & & & & & 38 \\
\hline
\end{tabular}

Note:

a) The figure indicates the number of positive observations, i.e. for the acquisition variable the number of firms that undertook cross-border acquisitions in 2000, and for the cross-listing variable the number of firms in the total sample that cross-listed on NYSE, NASDAQ, or LSE sometime during 1996-2000. 
Table II. Pearson Correlations, firm-specific variables

The table reports pairwise regular Pearson correlation coefficients for the included firm-level variables. $* *$ and $* * *$ indicate rejection of the null hypothesis of no correlation at the $5 \%$ and $1 \%$ significance level (2-tailed), respectively.

\begin{tabular}{|c|c|c|c|c|c|c|c|c|c|}
\hline & Sales/price & $\begin{array}{c}\text { Cost of } \\
\text { debt }\end{array}$ & $\begin{array}{c}\text { Internal } \\
\text { finnancing }\end{array}$ & Z"-score & Size & Intangibles & $\begin{array}{c}\text { Capital } \\
\text { intensity }\end{array}$ & $\begin{array}{c}\text { Sales/em- } \\
\text { ployee }\end{array}$ & $R O A$ \\
\hline Tobin's $q$ & $-0.36^{* * *}$ & $-0.11 * * *$ & $0.06^{* * *}$ & $0.68^{* * *}$ & $-0.08 * * *$ & $0.10^{* * *}$ & $-0.11 * * *$ & 0.05 & $0.27 * * *$ \\
\hline Sales/price & & $0.06^{* *}$ & $-0.09 * *$ & $-0.36 * * *$ & -0.02 & $-0.13 * * *$ & $-0.06 * *$ & $0.10^{* * *}$ & $-0.24 * * *$ \\
\hline Cost of debt & & & $-0.08^{* * *}$ & $-0.16^{* * *}$ & $-0.09 * * *$ & 0.01 & $0.17^{* * *}$ & -0.02 & -0.04 \\
\hline Internal financing & & & & $0.28 * * *$ & $0.07 * * *$ & 0.01 & $-0.18 * * *$ & 0.02 & $0.64 * * *$ \\
\hline Credit rating & & & & & $-0.19 * * *$ & 0.01 & $-0.26 * * *$ & -0.03 & $0.49 * * *$ \\
\hline Size & & & & & & $0.13^{* * *}$ & $0.14 * * *$ & $0.08^{* * *}$ & $0.06^{* *}$ \\
\hline Intangibles & & & & & & & $-0.27 * * *$ & $-0.08 * * *$ & 0.02 \\
\hline Capital intensity & & & & & & & & 0.00 & -0.02 \\
\hline Sales/employee & & & & & & & & & 0.04 \\
\hline
\end{tabular}




\section{Table III. Determinants of foreign acquisition likelihood, baseline cross-sectional regressions}

The table shows coefficient estimates from probit regressions of a foreign acquisition dummy on firm-specific characteristics. The dependent variable is an indicator variable taking on unit value if the firm undertook a cross-border acquisition during the sample period, and zero otherwise. The models use two different proxies for the cost of equity - Tobin's $q$ (models 1-3), and the sales/price ratio (models 4-6) -, other firm-level financial characteristics, and different combinations of traditional non-financial FDI determinants and control variables to estimate foreign-acquisition likelihood. Definitions of the included variables appear in Table A1 of the Appendix. All coefficients are reported with standard errors in parentheses. $*, * *$, and $* * *$ indicate rejection of the null hypothesis that the coefficient is equal to zero at the $10 \%, 5 \%$, and $1 \%$ significance level, respectively.

\begin{tabular}{|c|c|c|c|c|c|c|}
\hline & 1 & 2 & 3 & 4 & 5 & 6 \\
\hline Intercept & $-2.02(0.64)^{* * *}$ & $-2.55(0.37)^{* * *}$ & $-3.78(0.37)^{* * *}$ & $-1.64(0.67)^{* *}$ & $-2.47(0.40)^{* * *}$ & $-3.67(.38)^{* * *}$ \\
\hline \multicolumn{7}{|l|}{ Financial variables } \\
\hline Tobin's $q$ & $0.09(0.03)^{* * *}$ & $0.14(0.03)^{* * *}$ & $0.13(0.03)^{* * *}$ & & & \\
\hline Sales/price & & & & $-0.07(0.02)^{* * *}$ & $-0.04(0.02)^{* *}$ & $-0.04(0.02)^{* *}$ \\
\hline Cross-listing & $1.04(0.24)^{* * *}$ & $0.69(0.26)^{* * *}$ & $0.53(0.25)^{* *}$ & $1.14(0.25)^{* * *}$ & $0.76(0.27)^{* * *}$ & $0.60(0.26)^{* *}$ \\
\hline Cost of debt & $0.58(2.96)$ & $3.49(3.05)$ & $2.13(3.12)$ & $-0.15(3.04)$ & $3.43(3.06)$ & $1.78(3.14)$ \\
\hline Internal financing & $0.45(0.63)$ & & & $0.29(0.65)$ & & \\
\hline Credit rating & & & & $-0.02(0.01)$ & $0.04(0.02)^{* *}$ & $0.02(0.01)^{*}$ \\
\hline \multicolumn{7}{|l|}{$\frac{\text { Non-financial FDI }}{\text { determinants }}$} \\
\hline$\overline{\text { Size }}$ & & $0.29(0.03)^{* * *}$ & $0.31(0.03)^{* * *}$ & & $0.31(0.03)^{* * *}$ & $0.33(0.03)^{* * *}$ \\
\hline Intangibles & & $1.49(0.43)^{* * *}$ & $1.49(0.43)^{* * *}$ & & $1.45(0.45)^{* * *}$ & $1.29(0.44)^{* * *}$ \\
\hline Capital intensity & & $-0.33(0.27)$ & & & $-0.30(0.28)$ & \\
\hline Sales/employee & & $-0.11(0.07)$ & & & $-0.09(0.07)$ & \\
\hline ROA & & $0.37(0.60)$ & & & $-0.40(0.69)$ & \\
\hline Control variables $^{\mathrm{a}}$ & & & & & & \\
\hline Industry & Yes (16) & No & Yes (5) & Yes (17) & No & Yes (6) \\
\hline
\end{tabular}




\begin{tabular}{|c|c|c|c|c|c|c|}
\hline $\begin{array}{l}\text { dummies (\# sign.) } \\
\text { Source-country } \\
\text { dummies (\# sign.) }\end{array}$ & Yes (0) & No & No & Yes (0) & No & No \\
\hline Summary & & & & & & \\
\hline Obs. & 1342 & 1342 & 1371 & 1325 & 1327 & 1354 \\
\hline $\begin{array}{l}\text { McFadden pseudo- } \\
\mathrm{R}^{2}\end{array}$ & 0.08 & 0.17 & 0.20 & 0.09 & 0.18 & 0.21 \\
\hline Log likelihood & -601.1 & -540.4 & -522.0 & -586.7 & -525.7 & -513.0 \\
\hline $\begin{array}{l}\text { Test of exclusion } \\
\text { restrictions }\end{array}$ & $32.0 * * *$ & $31.6 * * *$ & $24.1 * * *$ & $36.0 * * *$ & $30.7 * * *$ & $20.9 * * *$ \\
\hline
\end{tabular}

Notes:

a) The figures in parentheses refer to the number of dummy control variables that are significant at least at the $10 \%$ confidence level.

b) Wald test $\left(\chi^{2}\right)$ for the exclusion of the included finance-related variables. Significance indicates rejection of the null hypothesis that coefficients for the included financerelated variables are jointly zero. 


\section{Table IV. Panel estimation of equity valuation-investment equations}

The table shows coefficient estimates from panel OLS regressions of yearly (1996-2000) observations of two equity valuation measures (Tobin's $q$ and the sales/price ratio) on one-year-ahead relative capital expenditure. The models are estimated with period fixed effects, and the coefficient estimates are reported with White standard errors robust to serial correlation and time-varying variances in parentheses. *** indicates rejection of the null hypothesis that the coefficient is equal to zero at the $1 \%$ significance level.

\begin{tabular}{l|cc}
\hline & \multicolumn{2}{|c}{ Dependent variable } \\
& Tobin's q (at time t) & Sales/price ratio (at time $t)$ \\
\hline Intercept & $1.45(0.04)^{* * *}$ & $3.13(0.10)^{* * *}$ \\
Capital expenditure (at time $t+1)$ & $0.46(0.10)^{* * *}$ & $-0.47(0.08)^{* * *}$ \\
& & \\
Fixed effects & Yes (period) & Yes (period) \\
Adj. $\mathrm{R}^{2}$ & 0.04 & 0.01 \\
Obs. & 4977 & 4942 \\
\hline
\end{tabular}




\section{Table V. Determinants of foreign acquisition likelihood, cross-sectional regres- sions with 'residual' equity valuation measures}

The table shows coefficient estimates from probit regressions of a foreign acquisition dummy on firmspecific characteristics. The dependent variable is an indicator variable taking on unit value if the firm undertook a cross-border acquisition during the sample period, and zero otherwise. The models estimate foreign-acquisition likelihood using cost of equity measures corrected for general investment opportunities - 'Residual $q$ ' (residuals from a regression of Tobin's $q$ on future relative capital expenditure; models 1-2), and 'Residual sales/price' (residuals from a regression of the sales/price ratio on future relative capital expenditure; models 3-4) -, other firm-level financial characteristics, and different combinations of traditional non-financial FDI determinants and control variables. Definitions of the included variables appear in Table A1 of the Appendix. Non-financial FDI determinants that turned out consistently insignificant in the baseline cross-sectional regressions (Table III) were dropped. All coefficients are reported with standard errors in parentheses. ${ }^{*}, * *$, and $* * *$ indicate rejection of the null hypothesis that the coefficient is equal to zero at the $10 \%, 5 \%$, and $1 \%$ significance level, respectively.

\begin{tabular}{|c|c|c|c|c|}
\hline & 1 & 2 & 3 & 4 \\
\hline Intercept & $-1.49(0.68)^{* *}$ & $-3.33(0.38)^{* * *}$ & $-1.65(0.71)^{* *}$ & $-3.71(0.40)^{* * *}$ \\
\hline \multicolumn{5}{|l|}{ Financial variables } \\
\hline Residual $q$ & $0.11(0.04)^{* * *}$ & $0.15(0.04)^{* * *}$ & & \\
\hline Residual sales/price & & & $-0.06(0.02) * * *$ & $-0.05(0.02)^{* *}$ \\
\hline Cross-listing & $1.03(0.25)^{* * *}$ & $0.41(0.25)$ & $1.18(0.26)^{* * *}$ & $0.51(0.27)^{*}$ \\
\hline Cost of debt & $0.30(3.10)$ & $2.99(3.31)$ & $-0.49(3.19)$ & $3.02(3.35)$ \\
\hline Internal financing & $0.71(0.66)$ & $-0.15(0.70)$ & $0.38(0.69)$ & $-1.04(0.74)$ \\
\hline Credit rating & & & $-0.01(0.01)$ & $0.04(0.01)^{* *}$ \\
\hline \multicolumn{5}{|l|}{ Non-financial FDI } \\
\hline determinants & & & & \\
\hline Size & & $0.30(0.03)^{* * *}$ & & $0.33(0.03)^{* * *}$ \\
\hline Intangibles & & $1.67(0.45)^{* * *}$ & & $1.42(0.46)^{* * *}$ \\
\hline \multicolumn{5}{|l|}{ Control variables ${ }^{\mathrm{a}}$} \\
\hline $\begin{array}{l}\text { Industry } \\
\text { dummies (\# sign.) }\end{array}$ & Yes (14) & Yes (4) & Yes (16) & Yes (4) \\
\hline $\begin{array}{l}\text { Source-country } \\
\text { dummies (\# sign.) }\end{array}$ & Yes $(0)$ & No & Yes $(0)$ & No \\
\hline \multicolumn{5}{|l|}{ Summary } \\
\hline Obs. & 1212 & 1209 & 1194 & 1191 \\
\hline $\begin{array}{l}\text { McFadden pseudo- } \\
\mathrm{R}^{2}\end{array}$ & 0.08 & 0.20 & 0.09 & 0.21 \\
\hline Log likelihood & -564.9 & -492.3 & -551.8 & -477.5 \\
\hline $\begin{array}{l}\text { Test of exclusion } \\
\text { restrictions }\end{array}$ & $33.6^{* * *}$ & $22.4^{* * *}$ & $36.8^{* * *}$ & $26.4 * * *$ \\
\hline
\end{tabular}

Notes: 
a) The figure in parentheses refers to the number of dummy control variables that are significant at least at the $10 \%$ confidence level.

b) Wald test $\left(\chi^{2}\right)$ for the exclusion of the included finance-related variables. Significance indicates rejection of the null hypothesis that coefficients for the included finance-related variables are jointly zero. 


\section{Table VI. Determinants of foreign acquisition likelihood, cross-sectional regres- sions with industry/finance interaction variables}

The table shows coefficient estimates from probit regressions of a foreign acquisition dummy on firmspecific characteristics. The dependent variable is an indicator variable taking on unit value if the firm undertook a cross-border acquisition during the sample period, and zero otherwise. The models estimate foreign-acquisition likelihood using cost of equity measures corrected for general investment opportunities - 'Residual $q$ ' (residuals from a regression of Tobin's $q$ on future relative capital expenditure; models 1 and 3), and 'Residual sales/price' (residuals from a regression of the sales/price ratio on future relative capital expenditure; models 2 and 4) -, other firm-level financial characteristics, traditional non-financial FDI determinants, and different combinations of interactivity between industry characteristics (as measured by the share of intangible assets and industry dummies) and the financerelated regressors. Definitions of the included variables appear in Table A1 of the Appendix. All coefficients are reported with standard errors in parentheses. ${ }^{*}, * *$, and $* * *$ indicate rejection of the null hypothesis that the coefficient is equal to zero at the $10 \%, 5 \%$, and $1 \%$ significance level, respectively.

\begin{tabular}{|c|c|c|c|c|}
\hline & 1 & 2 & 3 & 4 \\
\hline Intercept & $-2.84(0.21)^{* * *}$ & $-3.16(0.24)^{* * *}$ & $-2.86(0.22)^{* * *}$ & $-3.00(0.25)^{* * *}$ \\
\hline \multicolumn{5}{|l|}{ Financial variables } \\
\hline Residual $q$ & $0.68(0.46)$ & & $0.16(0.04)^{* * *}$ & \\
\hline Residual sales/price & & $-0.10(0.11)$ & & $-0.06(0.02)^{* * *}$ \\
\hline Cross-listing & $0.67(0.28)^{* *}$ & $0.45(0.27)^{*}$ & $0.39(0.27)$ & $0.57(0.27)^{* *}$ \\
\hline Cost of debt & $2.88(3.33)$ & $3.44(3.24)$ & $-8.27(11.8)$ & $2.11(3.40)$ \\
\hline Internal financing & $0.46(0.74)$ & $-0.63(0.74)$ & $-0.03(0.71)$ & $-0.73(0.74)$ \\
\hline Credit rating & & $0.04(0.01)^{* * *}$ & & $-0.07(0.08)$ \\
\hline \multicolumn{5}{|l|}{$\begin{array}{l}\text { Non-financial FDI determi- } \\
\text { nants }\end{array}$} \\
\hline Size & $0.28(0.03)^{* * *}$ & $0.31(0.03)^{* * *}$ & $0.28(0.03)^{* * *}$ & $0.31(0.03)^{* * *}$ \\
\hline Intangibles & $1.43(0.45)^{* * *}$ & $0.81(0.58)$ & $2.15(1.04)^{* *}$ & $-0.08(0.68)$ \\
\hline \multicolumn{5}{|l|}{ Interaction variables $^{\mathrm{a}}$} \\
\hline Intangibles $\times$ Residual $q$ & $1.96(0.48)^{* * *}$ & & & \\
\hline $\begin{array}{l}\text { Intangibles } \times \text { Residual } \\
\text { sales/price }\end{array}$ & & $-0.76(0.29)^{* * *}$ & & \\
\hline Intangibles $\times$ Cost of debt & & & $-11.5(34.5)$ & \\
\hline Intangibles $\times$ Credit rating & & & & $0.41(0.13)^{* * *}$ \\
\hline Industry $\times$ Residual $q^{\mathrm{a}}$ & $\begin{array}{c}\text { Machinery: } \\
-0.84(0.49)^{*} \\
\text { Utilities: } \\
-0.96(0.58)^{*} \\
\text { Vehicles: } \\
-0.93(0.52)^{*}\end{array}$ & & & \\
\hline $\begin{array}{l}\text { Industry } \times \text { Residual } \\
\text { sales/price }\end{array}$ & & None & & \\
\hline Industry $\times$ Cost of debt ${ }^{\mathrm{a}}$ & & & Electronics: & \\
\hline
\end{tabular}




\begin{tabular}{l|cccc} 
& \multicolumn{3}{|c}{$\begin{array}{c}25.6(12.7)^{* *} \\
\text { Services: } \\
\text { Industry } \times \text { Credit rating }\end{array}$} \\
& & & $22.7(12.9)^{*}$ & \\
& & & $0.22(0.10)^{* *}$ \\
Summary & & & \\
Obs. & 1209 & 1191 & 1209 & 1191 \\
McFadden pseudo- $\mathrm{R}^{2}$ & 0.21 & 0.20 & 0.19 & 0.21 \\
Log likelihood & -486.4 & -481.6 & -495.5 & -474.2 \\
\hline
\end{tabular}

Note:

a) Only coefficients significant at least at the $10 \%$ confidence level are shown. 


\section{Table VII. Determinants of foreign acquisition likelihood, cross-sectional regres- sions with financial-development/finance interaction variables}

The table shows coefficient estimates from probit regressions of a foreign acquisition dummy on firmspecific characteristics, allowing for interactivity between firms' financial characteristics and their home-country financial development. The dependent variable is an indicator variable taking on unit value if the firm undertook a cross-border acquisition during the sample period, and zero otherwise. The models estimate foreign-acquisition likelihood using cost of equity measures corrected for general investment opportunities - 'Residual $q$ ' (residuals from a regression of Tobin's $q$ on future relative capital expenditure; models 1, 3, and 4), and 'Residual sales/price' (residuals from a regression of the sales/price ratio on future relative capital expenditure; model 2) -, other firm-level financial characteristics, traditional non-financial FDI determinants, and different combinations of interactivity between the finance-related regressors and various measures of financial development in the firm's country of residence. Definitions of the included variables appear in Table A1 of the Appendix. All coefficients are reported with standard errors in parentheses. $*, * *$, and $* * *$ indicate rejection of the null hypothesis that the coefficient is equal to zero at the $10 \%, 5 \%$, and $1 \%$ significance level, respectively.

\begin{tabular}{|c|c|c|c|c|}
\hline & 1 & 2 & 3 & 4 \\
\hline Intercept & $-3.98(0.69)^{* * *}$ & $-4.68(0.78)^{* * *}$ & $-3.87(0.62)^{* * *}$ & $-3.86(0.64)^{* * *}$ \\
\hline \multicolumn{5}{|l|}{ Financial variables } \\
\hline Residual $q$ & $0.18(0.11)$ & & $0.16(0.12)$ & $-0.03(0.13)$ \\
\hline Residual sales/price & & $0.01(0.05)$ & & \\
\hline Cross-listing & $0.97(0.65)$ & $1.37(0.68)^{* *}$ & $1.01(0.71)$ & $1.24(0.68)^{*}$ \\
\hline Cost of debt & $-6.60(15.7)$ & $-3.32(16.6)$ & $-8.99(15.7)$ & $-10.4(15.8)$ \\
\hline Internal financing & $-0.66(0.75)$ & $-1.60(0.78)^{* *}$ & $-0.67(0.75)$ & $-0.53(0.74)$ \\
\hline Credit rating & & $0.16(0.06)^{* *}$ & & \\
\hline \multicolumn{5}{|l|}{ Non-financial FDI determi- } \\
\hline nants & & & & \\
\hline Size & $0.30(0.03)^{* * *}$ & $0.34(0.03)^{* * *}$ & $0.31(0.03)^{* * *}$ & $0.30(0.03)^{* * *}$ \\
\hline Intangibles & $2.01(0.50)^{* * *}$ & $1.79(0.52)^{* * *}$ & $2.01(0.50)^{* * *}$ & $1.99(0.50)^{* * *}$ \\
\hline \multicolumn{5}{|l|}{$\begin{array}{l}\text { Financial development vari- } \\
\text { ables }\end{array}$} \\
\hline Stock market cap & $0.17(0.34)$ & $0.28(0.35)$ & $0.24(0.18)$ & \\
\hline Equity issues & $0.34(1.41)$ & $-0.26(1.44)$ & & $0.78(0.76)$ \\
\hline Private credit & $0.15(0.59)$ & $0.54(0.72)$ & $0.02(0.52)$ & $0.04(0.49)$ \\
\hline Shareholder rights & $0.11(0.08)$ & $0.05(0.09)$ & $0.12(0.07)$ & $0.11(0.08)$ \\
\hline Creditor rights & $0.09(0.11)$ & $0.19(0.13)$ & $0.08(0.10)$ & $0.08(0.10)$ \\
\hline \multicolumn{5}{|l|}{ Interaction variables } \\
\hline $\begin{array}{l}\text { Stock market cap } \times \text { Resid- } \\
\text { ual } q\end{array}$ & $-0.23(0.10)^{* *}$ & & $-0.20(0.10)^{* *}$ & \\
\hline $\begin{array}{l}\text { Shareholder rights } \times \text { Resid- } \\
\text { ual } q\end{array}$ & $0.08(0.05)^{*}$ & & $0.07(0.05)$ & $0.04(0.05)$ \\
\hline
\end{tabular}




\begin{tabular}{|c|c|c|c|c|}
\hline Equity issues $\times$ Residual $q$ & & & & $0.34(0.44)$ \\
\hline $\begin{array}{l}\text { Stock market cap } \times \text { Resid- } \\
\text { ual sales/price }\end{array}$ & & $-0.04(0.08)$ & & \\
\hline $\begin{array}{l}\text { Shareholder rights } \times \text { Resid- } \\
\text { ual sales/price }\end{array}$ & & $-0.03(0.02)$ & & \\
\hline $\begin{array}{l}\text { Stock market cap } \times \text { Cross- } \\
\text { listing }\end{array}$ & & & $-0.70(0.90)$ & \\
\hline $\begin{array}{l}\text { Equity issues } \times \text { Cross- } \\
\text { listing }\end{array}$ & $-1.66(2.11)$ & $-2.39(2.15)$ & & $-2.71(2.22)$ \\
\hline Private credit $\times$ Cost of debt & $5.13(16.6)$ & $1.49(17.9)$ & $7.72(16.6)$ & $8.71(16.7)$ \\
\hline $\begin{array}{l}\text { Creditor rights } \times \text { Cost of } \\
\text { debt }\end{array}$ & $3.15(3.28)$ & $2.60(3.37)$ & $3.44(3.28)$ & $3.30(3.27)$ \\
\hline $\begin{array}{l}\text { Private credit } \times \text { Credit rat- } \\
\text { ing }\end{array}$ & & $-0.09(0.07)$ & & \\
\hline $\begin{array}{l}\text { Creditor rights } \times \text { Credit } \\
\text { rating }\end{array}$ & & $-0.03(0.01)^{* *}$ & & \\
\hline Control variables $^{\mathrm{a}}$ & & & & \\
\hline $\begin{array}{l}\text { Industry } \\
\text { dummies (\# sign.) }\end{array}$ & Yes (3) & Yes (3) & Yes (3) & Yes (2) \\
\hline Summary & & & & \\
\hline Obs. & 1161 & 1144 & 1161 & 1161 \\
\hline McFadden pseudo- $\mathrm{R}^{2}$ & 0.22 & 0.23 & 0.22 & 0.21 \\
\hline Log likelihood & -456.5 & -439.5 & -456.5 & -459.1 \\
\hline
\end{tabular}

Note:

a) The figures in parentheses refer to the number of industry dummies that are significant at least at the $10 \%$ confidence level. 


\section{Table VIII. Estimation result of the host-country sample selection model}

The table shows coefficient estimates from probit regressions of a selection dummy variable on basic country characteristics. The dependent variable is an indicator variable taking on unit value if the country was included in the sample of potential host countries in the regressions estimating foreignacquisition likelihood using both firm- and host-country-level regressors (reported in Table IX). The independent variables proxy for target market size (population), level of development (income), corruption/political risk (transparency and accountability), and distance (dummy variables indicating the geographical region of the country). These selection regressions constitute the first step in the Heckman (1979) two-step approach to correcting for potential selection bias. All coefficients are reported with standard errors in parentheses. $* * *$ indicates rejection of the null hypothesis that the coefficient is equal to zero at the $1 \%$ significance level.

\begin{tabular}{|c|c|c|c|c|}
\hline & 1 & 2 & 3 & 4 \\
\hline Intercept & $-6.46(1.10)^{* * *}$ & $-13.6(2.89)^{* * *}$ & $-16.1(2.99)^{* * *}$ & $-8.56(1.27)^{* * *}$ \\
\hline Population & $0.52(0.10)^{* * *}$ & $0.99(0.24) * * *$ & $1.04(0.22)^{* * *}$ & $0.67(0.11)^{* * *}$ \\
\hline Income & $0.92(0.15)^{* * *}$ & $1.54(0.36)^{* * *}$ & & \\
\hline Transparency & & & $0.94(0.20)^{* * *}$ & \\
\hline Accountability & & & & $1.06(0.25)^{* * *}$ \\
\hline $\begin{array}{l}\text { Geographical } \\
\text { dummies (\# } \\
\text { sign.) })^{\mathrm{a}}\end{array}$ & No & Yes (3) & Yes (3) & Yes (4) \\
\hline Obs. & 176 & 176 & 176 & 176 \\
\hline $\begin{array}{l}\text { McFadden } \\
\text { pseudo- } \mathrm{R}^{2}\end{array}$ & 0.55 & 0.75 & 0.74 & 0.62 \\
\hline Log likelihood & -45.1 & -24.6 & -25.5 & -37.5 \\
\hline
\end{tabular}

Note:

a) The figures in parentheses refer to the number of industry dummies that are significant at least at the $10 \%$ confidence level. 


\section{Table IX. Determinants of foreign acquisition likelihood, pooled regressions with both firm-level and host-country-level regressors}

The table shows coefficient estimates from regressions of a foreign acquisition dummy on both firm-specific and host-country-specific characteristics. The dependent variable is an indicator variable taking on unit value if the firm undertook a cross-border acquisition during the sample period, and zero otherwise. The models estimate foreignacquisition likelihood using cost of equity measures corrected for general investment opportunities - 'Residual $q$ ' (residuals from a regression of Tobin's $q$ on future relative capital expenditure; models 1-3), and 'Residual sales/price' (residuals from a regression of the sales/price ratio on future relative capital expenditure; model 4) -, other firmlevel financial characteristics, traditional non-financial firm-level FDI determinants, and traditional host-country-level FDI determinants. The regressions control for possible sample selection bias as regards the included host-country sample in the sense of Heckman (1979) by the inclusion of a host-country-specific correction variable ('lambda' the inverse Mills ratio from specification 2 in Table VIII). Definitions of the other included variables appear in Table A1 of the Appendix. All coefficients are reported with standard errors in parentheses. The linear regression (Model 4) is estimated with random effects in both the cross-sectional (firm) and the host-country dimension, and reported with regular White heteroscedasticity-robust standard errors. ** and *** indicate rejection of the null hypothesis that the coefficient is equal to zero at the $5 \%$ and $1 \%$ significance level, respectively.

\begin{tabular}{|c|c|c|c|c|c|}
\hline & 1. Pooled probit & 2. Pooled probit & 3. Pooled probit & $\begin{array}{l}\text { 4. Pooled least squares } \\
\text { (2-way random effects) }\end{array}$ & $\begin{array}{l}\text { 5. Pooled least squares } \\
\text { (2-way random effects) }\end{array}$ \\
\hline Intercept & $-5.67(0.67)^{* * *}$ & $-6.04(0.44) * * *$ & $-5.78(0.68)^{* * *}$ & $-0.08(0.03)^{* *}$ & $-0.08(0.03)^{* *}$ \\
\hline \multicolumn{6}{|l|}{ Financial variables } \\
\hline Residual $q$ & $0.06(0.01)^{* * *}$ & $0.06(0.01)^{* * *}$ & & $0.001(0.001)$ & \\
\hline Residual sales/price & & & $-0.03(0.01)^{* * *}$ & & $-3.6 \times 10^{-4}\left(1.3 \times 10^{-4}\right)^{* * *}$ \\
\hline Cross-listing & $0.23(0.08)^{* * *}$ & $0.22(0.08)^{* * *}$ & $0.23(0.08)^{* * *}$ & $0.02(0.01)^{* *}$ & $0.02(0.01)^{* *}$ \\
\hline Cost of debt & $0.61(1.64)$ & $0.62(1.62)$ & $0.67(1.64)$ & $0.02(0.04)$ & $0.03(0.04)$ \\
\hline Internal financing & $-0.38(0.33)$ & $-0.37(0.33)$ & $-0.87(0.34)^{* *}$ & $-0.004(0.009)$ & $-0.01(0.01)$ \\
\hline Credit rating & & & $0.02(0.01)^{* * *}$ & & $3.2 \times 10^{-4}\left(2.0 \times 10^{-4}\right)$ \\
\hline
\end{tabular}




\begin{tabular}{|c|c|c|c|c|c|}
\hline Size & $0.19(0.01)^{* * *}$ & $0.18(0.01)^{* * *}$ & $0.20(0.01)^{* * *}$ & $0.003(0.001)^{* * *}$ & $0.004(0.001)^{* * *}$ \\
\hline Intangibles & $1.06(0.18)^{* * *}$ & $1.04(0.17)^{* * *}$ & $0.93(0.18)^{* * *}$ & $0.03(0.01)^{* * *}$ & $0.03(0.01)^{* * *}$ \\
\hline \multicolumn{6}{|l|}{ Host-country FDI determinants } \\
\hline Market size (GDP) & $0.25(0.02)^{* * *}$ & & $0.25(0.02)^{* * *}$ & $0.005(0.001)^{* * *}$ & $0.005(0.001)^{* * *}$ \\
\hline Population & & $0.19(0.02)^{* * *}$ & & & \\
\hline Income & $-0.18(0.07)^{* *}$ & & $-0.19(0.07)^{* *}$ & $0.000(0.001)$ & $0.000(0.06)$ \\
\hline Wage & & $-0.01(0.03)$ & & & \\
\hline Tax & $-0.10(0.07)$ & $-0.02(0.07)$ & $-0.09(0.07)$ & $-0.004(0.002)^{* *}$ & $-0.003(0.002)^{*}$ \\
\hline Accountability & $0.48(0.07)^{* * *}$ & & $0.49(0.07)^{* * *}$ & $0.006(0.001)^{* * *}$ & $0.006(0.001)^{* * *}$ \\
\hline Political stability & & $0.42(0.06)^{* * *}$ & & & \\
\hline $\begin{array}{l}\text { Country selection correction } \\
\text { (lambda) }\end{array}$ & $-0.48(0.30)$ & $-1.13(0.32)^{* * *}$ & $-0.50(0.31)$ & $0.008(0.01)$ & $0.008(0.01)$ \\
\hline \multicolumn{6}{|l|}{ Control variables $^{\mathrm{a}}$} \\
\hline $\begin{array}{l}\text { Industry } \\
\text { dummies (\# sign.) }\end{array}$ & Yes (7) & Yes (7) & Yes (7) & Yes (3) & Yes (6) \\
\hline \multicolumn{6}{|l|}{ Summary } \\
\hline Obs. & 51686 & 51686 & 50912 & 51686 & 50912 \\
\hline Regression F & & & & $13.7^{* * *}$ & $13.9^{* * *}$ \\
\hline Durbin-Watson & & & & 1.95 & 1.96 \\
\hline Adj. R (weighted) & & & & 0.01 & 0.01 \\
\hline McFadden pseudo- $\mathrm{R}^{2}$ & 0.18 & 0.17 & 0.19 & & \\
\hline Log likelihood & -1881.4 & -1912.3 & -1840.0 & & \\
\hline
\end{tabular}

Note:

a) The figures in parentheses refer to the number of industry dummies that are significant at least at the $10 \%$ confidence level. 


\section{Table X. Determinants of the number of foreign acquisitions}

The table shows coefficient estimates from negative binomial regressions of the number of foreign acquisitions on firm-specific characteristics. The dependent variable is a count variable indicating the number of cross-border acquisitions undertaken by a firm during the sample period. The models estimate foreign-acquisition likelihood using cost of equity measures corrected for general investment opportunities - 'Residual $q$ ' (residuals from a regression of Tobin's $q$ on future relative capital expenditure; model 1), and 'Residual sales/price' (residuals from a regression of the sales/price ratio on future relative capital expenditure; model 2) -, other firm-level financial characteristics, traditional nonfinancial FDI determinants, and industry control variables. Definitions of the included variables appear in Table A1 of the Appendix. Non-financial FDI determinants that turned out consistently insignificant in the baseline cross-sectional regressions (Table III) were dropped (excepting the dependent variable, specifications below are identical to those in Table IV, models 2 and 4). All coefficients are reported with standard errors in parentheses. $* *$ and $* * *$ indicate rejection of the null hypothesis that the coefficient is equal to zero at the $5 \%$ and $1 \%$ significance level, respectively.

\begin{tabular}{l|cc}
\hline & 1 & 2 \\
\hline Intercept & $-5.46(0.70)^{* * * *}$ & $-5.96(0.70)^{* * *}$ \\
Financial variables & & \\
Residual $q$ & $0.24(0.06)^{* * *}$ & $-0.09(0.03)^{* * *}$ \\
Residual sales/price & $0.33(0.31)$ & $0.32(0.30)$ \\
Cross-listing & $1.24(5.24)$ & $1.10(5.13)$ \\
Cost of debt & $-0.79(1.05)$ & $-2.09(1.07)^{* *}$ \\
Internal financing & & $0.05(0.02)^{* *}$ \\
Credit rating & & \\
Non-financial FDI determinants & $0.52(0.04)^{* * *}$ & $0.55(0.04)^{* * *}$ \\
Size & $2.48(0.65)^{* * *}$ & $2.03(0.63)^{* * *}$ \\
Intangibles & & \\
Control variables & & \\
Industry & Yes $(2)$ & Yes $(3)$ \\
dummies (\# sign.) & & \\
Summary & & 1191 \\
\hline Obs. & 1209 & 0.28 \\
Adj. R & 0.13 & -810.9 \\
Log likelihood & -835.0 & \\
\hline
\end{tabular}

Notes:

a) The figures in parentheses refer to the number of industry dummies that are significant at least at the $10 \%$ confidence level. 
Table A1. Variable definitions

\begin{tabular}{|c|c|c|}
\hline Variable & Description & Source \\
\hline Dependent variables & & \\
\hline ACQ (acquisition indicator) & $\begin{array}{l}\text { Takes on unit value if a foreign acquisition was } \\
\text { undertaken in } 2000 \text {, zero otherwise }\end{array}$ & $\begin{array}{c}\text { Thomson M\&A } \\
\text { database }\end{array}$ \\
\hline $\begin{array}{l}\text { NOACQ (integer count } \\
\text { variable) }\end{array}$ & Number of foreign acquisitions undertaken in 2000 & As above \\
\hline \multicolumn{3}{|l|}{ Financial variables } \\
\hline$\overline{\text { Cross-listing }}$ & $\begin{array}{l}\text { Dummy variable taking on unit value if the firm } \\
\text { cross-listed on NYSE, NASDAQ, or LSE in any of } \\
\text { the years 1996-2000, zero otherwise }\end{array}$ & $\begin{array}{l}\text { Annual reports } \\
\text { and fact books } \\
\text { from each stock } \\
\text { exchange }\end{array}$ \\
\hline Tobin's $q$ & The sum of market value of equity and book value & COMPUSTAT \\
\hline & $\begin{array}{l}\text { of total liabilities divided by the book value of total } \\
\text { assets }^{\text {a }}\end{array}$ & $\begin{array}{c}\text { Global Industrial } \\
\text { database }\end{array}$ \\
\hline Sales/price ratio & Total sales divided by market value ${ }^{\mathrm{a}}$ & As above \\
\hline Cost of debt & $\begin{array}{l}\text { Average cost of debt: natural logarithm of }(1+\text { in- } \\
\text { terest expenditure over total liabilities })^{\mathrm{a}}\end{array}$ & As above \\
\hline Credit rating & Average Z"-score & As above \\
\hline Internal financing & Free cash flow divided by total assets ${ }^{\mathrm{a}}$ & As above \\
\hline \multicolumn{3}{|l|}{ Non-financial firm-level } \\
\hline FDI determinants & & \\
\hline Size & $\begin{array}{l}\text { Natural logarithm of total assets in thousands of } \\
\text { USD }^{\mathrm{a}}\end{array}$ & As above \\
\hline Intangibles & Intangible assets over total assets ${ }^{\mathrm{a}}$ & As above \\
\hline Capital intensity & $\begin{array}{l}\text { Plants, property, and equipment (total, net) divided } \\
\text { by total assets }{ }^{\mathrm{a}}\end{array}$ & As above \\
\hline Sales/employee & $\begin{array}{l}\text { Natural logarithm of the ratio of total sales (in thou- } \\
\text { sands of USD) to number of employees }\end{array}$ & As above \\
\hline $\mathrm{ROA}$ & Return on assets: EBIT divided by total assets ${ }^{\mathrm{a}}$ & As above \\
\hline \multicolumn{3}{|l|}{ Other firm-specific vari- } \\
\hline 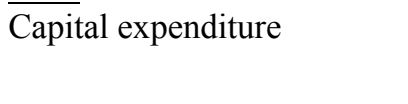 & $\begin{array}{l}\text { Capital expenditure at time } t \text { divided by Plants, } \\
\text { property, and equipment (total, net) at time } t-1\end{array}$ & As above \\
\hline \multicolumn{2}{|l|}{ Financial-development } & \\
\hline Stock market cap & Stock market capitalization divided by GDP ${ }^{\mathrm{a}}$ & Eurostat, IFS \\
\hline Equity issues & $\begin{array}{l}\text { Net equity issues divided by gross fixed capital } \\
\text { formation }^{\text {a }}\end{array}$ & $\begin{array}{l}\text { Eurostat, Data- } \\
\text { stream, IFS }\end{array}$ \\
\hline Private credit & Credit to the private sector divided by GDP ${ }^{\mathrm{a}}$ & IFS \\
\hline Shareholder rights & $\begin{array}{l}\text { Index of anti-director rights; higher value indicates } \\
\text { better shareholder protection }\end{array}$ & $\begin{array}{l}\text { La Porta et al. } \\
\text { (1998) }\end{array}$ \\
\hline Creditor rights & $\begin{array}{l}\text { Index of creditor rights; higher value indicates bet- } \\
\text { ter creditor protection }\end{array}$ & As above \\
\hline \multicolumn{3}{|l|}{ Host-country variables } \\
\hline$\overline{\text { Market size }}$ & Natural logarithm of GDP in mn USD ${ }^{a}$ & IFS/WDI \\
\hline Population & Log of population in thousands ${ }^{\mathrm{a}}$ & As above \\
\hline Income & Log of GDP/capita in '000 USD'a & As above \\
\hline Wage & $\begin{array}{l}\text { Log of the average monthly USD manufacturing } \\
\text { wages }^{\mathrm{a}}\end{array}$ & As above \\
\hline Tax & $\begin{array}{l}\text { The target country's statutory corporate income tax } \\
\text { rate, observed in } 1999\end{array}$ & $\begin{array}{l}\text { Pricewaterhouse- } \\
\text { Coopers (2000) }\end{array}$ \\
\hline Transparency & $\begin{array}{l}\text { Corruption's Perception Index (CPI), observed in } \\
\text { 2003; higher index value indicates less corruption }\end{array}$ & $\begin{array}{l}\text { Transparency } \\
\text { International }\end{array}$ \\
\hline Accountability & Index of 'Voice and accountability', observed in & Kaufmann et al. \\
\hline
\end{tabular}


$2000^{c}$; higher index value indicates more democracy

Index of 'Political stability', observed in $2000^{c}$; higher index value indicates lower political risk
(2003)

As above

\section{Notes:}

a) These variables are observed for the years 1996-2000, and used in the cross-sectional regressions as the average of these yearly observations.

b) $Z "=6.56 \times($ Working Capital/Total Assets $)+3.26 \times($ Retained Earnings/Total Assets $)+6.72 \times$

$($ EBIT/Total Assets $)+1.05 \times($ Market Value of Equity/Book Value of Total Liabilities); see Altman (2002).

c) In a small number of cases, where data were unavailable for 2000, observations are from 2002. 
Table A2. Descriptive statistics, source country variables

\begin{tabular}{l|ccccc}
\hline & Obs. & Mean & Std. dev. & Min. & Max. \\
\hline Stock market cap. & 12 & 0.64 & 0.30 & 0.16 & 1.33 \\
Equity issues & 12 & 0.23 & 0.09 & 0.04 & 0.65 \\
Private credit & 12 & 0.74 & 0.23 & 0.42 & 1.19 \\
Shareholder rights & 12 & 2.08 & 1.13 & 0.00 & 4.00 \\
Creditor rights & 12 & 1.67 & 1.18 & 0.00 & 3.00 \\
\hline
\end{tabular}


Table A3. Descriptive statistics, host country variables

\begin{tabular}{l|ccccc}
\hline & Obs. & Mean & Std. dev. & Min. & Max. \\
\hline Market size & 44 & 12.497 & 1.390 & 9.460 & 15.980 \\
Population & 44 & 9.915 & 1.397 & 7.250 & 14.030 \\
Income & 44 & 9.491 & 0.653 & 8.030 & 10.380 \\
Wage & 44 & 6.721 & 1.044 & 4.520 & 9.480 \\
Tax & 44 & 3.349 & 0.306 & 2.140 & 3.689 \\
Transparency & 44 & 6.091 & 2.355 & 2.500 & 9.700 \\
Accountability & 44 & 0.838 & 0.682 & -1.370 & 1.640 \\
Political stability & 44 & 0.81 & 0.63 & -0.99 & 1.73 \\
\hline
\end{tabular}


Table A4. Pearson correlations, host country variables

$* *$ and $* * *$ indicate rejection of the null hypothesis of no correlation at the $5 \%$ and $1 \%$ significance level (2-tailed), respectively.

\begin{tabular}{|c|c|c|c|c|c|c|c|}
\hline & $\begin{array}{c}\text { Market } \\
\text { size }\end{array}$ & $\begin{array}{c}\text { Popula- } \\
\text { tion }\end{array}$ & Income & Wage & $\operatorname{Tax}$ & $\begin{array}{c}\text { Trans- } \\
\text { parency }\end{array}$ & $\begin{array}{c}\text { Account } \\
\text { ability }\end{array}$ \\
\hline Population & $0.89 * * *$ & & & & & & \\
\hline Income & 0.23 & -0.24 & & & & & \\
\hline Wage & 0.25 & -0.09 & $0.73 * * *$ & & & & \\
\hline Tax & $0.34 * *$ & $0.30 * *$ & 0.08 & 0.08 & & & \\
\hline Transparency & 0.03 & $-0.36 * *$ & $0.83 * * *$ & $0.71 * * *$ & -0.02 & & \\
\hline Accountability & -0.14 & $-0.42 * * *$ & $0.60 * * *$ & $0.39 * * *$ & 0.03 & $0.60 * * *$ & \\
\hline Political stability & -0.03 & $-0.42 * * *$ & $0.82 * * *$ & $0.58 * * *$ & -0.07 & $0.85 * * *$ & $0.71 * * *$ \\
\hline
\end{tabular}


Table A5. Descriptive statistics, variables included in selection model

\begin{tabular}{l|ccccc}
\hline & Obs. & Mean & Std. dev. & Min. & Max. \\
\hline Market size & 176 & 9.29 & 2.43 & 3.77 & 15.99 \\
Population & 176 & 8.62 & 2.00 & 3.69 & 14.04 \\
Income & 176 & 0.66 & 1.60 & -2.38 & 3.84 \\
Transparency & 176 & 4.28 & 1.96 & 1.30 & 9.70 \\
Accountability & 174 & 0.03 & 0.95 & -2.12 & 1.64 \\
Political stability & 167 & 0.08 & 0.97 & -2.83 & 1.73 \\
& & & & & \\
Dummy variables & \\
Selection indicator & 44 & & & & \\
(dependent var.) & & & & & \\
EU & 15 & & & & \\
Europe, other & 29 & & & & \\
North America & 15 & & & & \\
Latin America & 20 & 34 & & & \\
Asia/Oceania & 63 & & & & \\
Africa/Middle East & 60 & & & & \\
OECD & & & & & \\
\hline
\end{tabular}

Note:

a) The figures indicate the number of positive observations. 
Table A6. Pearson correlations, variables included in selection model

$* *$ and $* * *$ indicate rejection of the null hypothesis of no correlation at the $5 \%$ and $1 \%$ significance level (2-tailed), respectively.

\begin{tabular}{|c|c|c|c|c|c|c|}
\hline & $\begin{array}{c}\text { Market } \\
\text { size }\end{array}$ & Population & Income & $\begin{array}{c}\text { Transpar- } \\
\text { ency }\end{array}$ & $\begin{array}{c}\text { Account- } \\
\text { ability }\end{array}$ & $\begin{array}{l}\text { Political } \\
\text { stability }\end{array}$ \\
\hline Population & $0.75 * * *$ & & & & & \\
\hline Income & $0.57 * * *$ & -0.11 & & & & \\
\hline Transparency & $0.33 * * *$ & $-0.15^{* *}$ & $0.69 * * *$ & & & \\
\hline Accountability & $0.21 * * *$ & $-0.22 * * *$ & $0.59 * * *$ & $0.60 * * *$ & & \\
\hline Political stability & $0.23 * * *$ & $-0.28 * * *$ & $0.66^{* * *}$ & $0.69 * * *$ & $0.70 * * *$ & \\
\hline Rule of law & $0.49 * * *$ & -0.06 & $0.82 * * *$ & $0.84 * * *$ & $0.72 * * *$ & $0.78 * * *$ \\
\hline
\end{tabular}

